\title{
Preparation of Phosphorescent Osmium(IV) Complexes with N,N',C- and C,N,C'-Pincer Ligands
}

\author{
Roberto G. Alabau, Miguel A. Esteruelas,* Montserrat Oliván, and Enrique Oñate \\ Departamento de Química Inorgánica - Instituto de Síntesis Química y Catálisis Homogénea (ISQCH) - Centro de Innova- \\ ción en Química Avanzada (ORFEO-CINQA), Universidad de Zaragoza - CSIC, 50009 Zaragoza, Spain \\ Supporting Information Placeholder
}

\begin{abstract}
Four different pincer ligands, which prove that the disposition of the donor atoms in pincer ligands allows them to develop a marked ability to form less common coordination polyhedra and to favor unusual metal oxidation states, have been generated starting from $\mathrm{OsH}_{6}\left(\mathrm{P}^{\mathrm{i}} \mathrm{Pr}_{3}\right)_{2}$ and 2-phenyl-6-(1H-pyrazol-3-yl)pyridine (Hpz-py-Ph) in order to stabilize phosphorescent, pentagonal bipyramidal, osmium(IV) emitters. Complex 1 reacts with the disubstituted heterocycle to give OsH ${ }_{2}\left\{\kappa^{3}-N, N^{\prime}, C\right.$ - $(\mathrm{pz}-\mathrm{py}-$ $\left.\left.\mathrm{C}_{6} \mathrm{H}_{4}\right)\right\}\left(\mathrm{P}^{\mathrm{i}} \mathrm{Pr}_{3}\right)_{2}(2)$, as a result of the activation of a phenyl ortho-CH bond and the pyrazolyl $\mathrm{NH}$ of the pyridine substituents. The addition of methyl trifluoromethanesulfonate (MeOTf) to 2 produces the methylation of the free $\mathrm{N}$ atom of the pz group and the formation of the salt $\left[\mathrm{OsH}_{2}\left\{\kappa^{3}-N, N^{\prime}, C\right.\right.$ - $\left.\left.\left(\mathrm{Mepz}-\mathrm{py}_{-}-\mathrm{C}_{6} \mathrm{H}_{4}\right)\right\}\left(\mathrm{P}^{\mathrm{i}} \mathrm{Pr}_{3}\right)_{2}\right] \mathrm{OTf}(\mathbf{3})$, which undergoes deprotonation of the metal center in the presence of $\mathrm{KO}^{t} \mathrm{Bu}$. The resulting monohydride $\mathrm{OsH}\left\{\kappa^{3}-N, N^{\prime}, C\right.$-(Mepz-py- $\left.\left.\mathrm{C}_{6} \mathrm{H}_{4}\right)\right\}\left(\mathrm{P}^{\mathrm{i}} \mathrm{Pr}_{3}\right)_{2}(4)$ is unstable and evolves into $\mathrm{OsH}_{2}\left\{\kappa^{3}-\right.$ $C, N, C^{\prime}$-(Mepz-py- $\left.\left.\mathrm{C}_{6} \mathrm{H}_{4}\right)\right\}\left(\mathrm{P}^{\mathrm{i}} \mathrm{Pr}_{3}\right)_{2}(\mathbf{5})$ as a consequence of the oxidative addition of the $\mathrm{C}-\mathrm{H}$ bond at position 4 of the Mepz group to the osmium atom of $\mathbf{4}$. The addition of MeOTf to $\mathbf{5}$ produces the methylation of the free $\mathrm{N}$ atom of the Mepz group, which is converted in a remote $\mathrm{N}$-heterocyclic carbene, to form $\left[\mathrm{OsH}_{2}\left\{\kappa^{3}-C, N, C^{\prime}-\left(\mathrm{Me}_{2}\right.\right.\right.$ pz-py- $\left.\left.\left.\mathrm{C}_{6} \mathrm{H}_{4}\right)\right\}\left(\mathrm{P}^{\mathrm{i}} \mathrm{Pr}_{3}\right)_{2}\right] \mathrm{OTf}(\mathbf{6})$. Complex 1 also reacts with 2-(1H-pyrazol-3-yl)pyridine (Hpz-py). The reaction gives rise to the trihydride derivative $\mathrm{OsH}_{3}\left\{\kappa^{2}-N, N-(\mathrm{pz}-\mathrm{py})\right\}\left(\mathrm{P}^{\mathrm{i}} \mathrm{Pr}_{3}\right)_{2}(7)$, which leads to the salt $\left[\mathrm{OsH}_{3}\left\{\kappa^{2}-N, N\right.\right.$-(Mepz-py) $\left.\}\left(\mathrm{P}^{\mathrm{i}} \mathrm{Pr}_{3}\right)_{2}\right] \mathrm{OTf}(\mathbf{8})$ by addition of MeOTf. The deprotonation of 8 affords the osmium(II)-dihydride $\mathrm{OsH}_{2}\left\{\kappa^{2}-N, N\right.$-(Mepz-py) $\}\left(\mathrm{P}^{1} \mathrm{Pr}_{3}\right)_{2}$ (9), which in contrast to $\mathbf{4}$ is stable. Complexes 2, 3, 5, 7, and 8 are emissive in the green-to-red region upon photoexcitation.
\end{abstract}

\section{INTRODUCTION}

Osmium(II) based phosphorescent emitters for OLED applications have awakened a great deal of interest. ${ }^{1}$ Their octahedral ligand arrangement resembles that of iridium(III). However, the osmium(II) complexes usually exhibit a shallower HOMO energy level. As a consequence, they show a more difficult color tuning, in particular at the higher energy region, due to the small band gap. ${ }^{2}$ The HOMO level of osmium(IV) complexes with structure of pentagonal bipyramid is deeper, resulting in principle easier to reach the higher energy region. Osmium(IV) complexes may offer a great deal of flexibility for color tuning, in addition to be more difficult to oxidize than osmium(II) derivatives. Furthermore, OLEDs utilizing osmium(IV) based emitters should be more immune from formation of exciplex in the device.

Osmium(IV)-based PHOLEDs are certainly promising and their development is a challenge. However, emissive osmium(IV) complexes have received scarce attention in part due to the difficulty of their preparation and to the fact that several structures close in energy are possible for these compounds. The facile interconversion between them allows the dynamic quenching of the phosphorescence. As a result, the emissive osmium(IV) complexes reported until now are extremely rare and are characterized by their low stability and quantum efficiency lower than $0.06 .{ }^{3}$ So, the field demands to resolve two urgent needs: to increase the stability of complexes and the quantum yield of their emissions.
It is well known that there is a very marked relationship between the geometry of a complex and the oxidation state of its metal center. It is also known that the disposition of the donor atoms of the polydentate ligands determines the geometry of the complexes. As a result, there are ligands that facilitate the stabilization of compounds with the metal center in a given oxidation state. This has been used in the polyhydrides chemistry to favor the dihydrogen form versus dihydride structures. ${ }^{4}$ In addition, it has been proved that pincer ligands forming two five-membered metalarings provide rigidity to the geometry of their derivatives preventing fluxional processes. ${ }^{5}$ Thus, these ligands are excellent candidates to stabilize rigid osmium(IV) species with pentagonal bipyramid structure, since generate two consecutive angles close to $72^{\circ}$ which is the ideal L-M-L angle in the equatorial plane of the bipyramid.

A type of molecule that could afford pincer ligands with the characteristics above mentioned is 2-phenyl-6-(1H-pyrazol-3yl)pyridine and its functionalized derivatives. ${ }^{6}$ These molecules can afford monoanionic C,N,N-pincer ligands by selective ortho- $\mathrm{CH}$ bond activation of the phenyl substituent of the pyridine and dianionic $\mathrm{C}, \mathrm{N}, \mathrm{N}$-pincer ligands by activation of both an ortho- $\mathrm{CH}$ bond of the phenyl substituent and the pyrazolyl N-H bond. Monoanionic and dianionic ligands of this type have been used to stabilize emissive platinum(II) complexes with good quantum yields, ${ }^{7}$ whereas the dianionic type ligands along with other monoanionic pincer group have been employed to form bis(tridentate) heteroleptic iridium(III) 


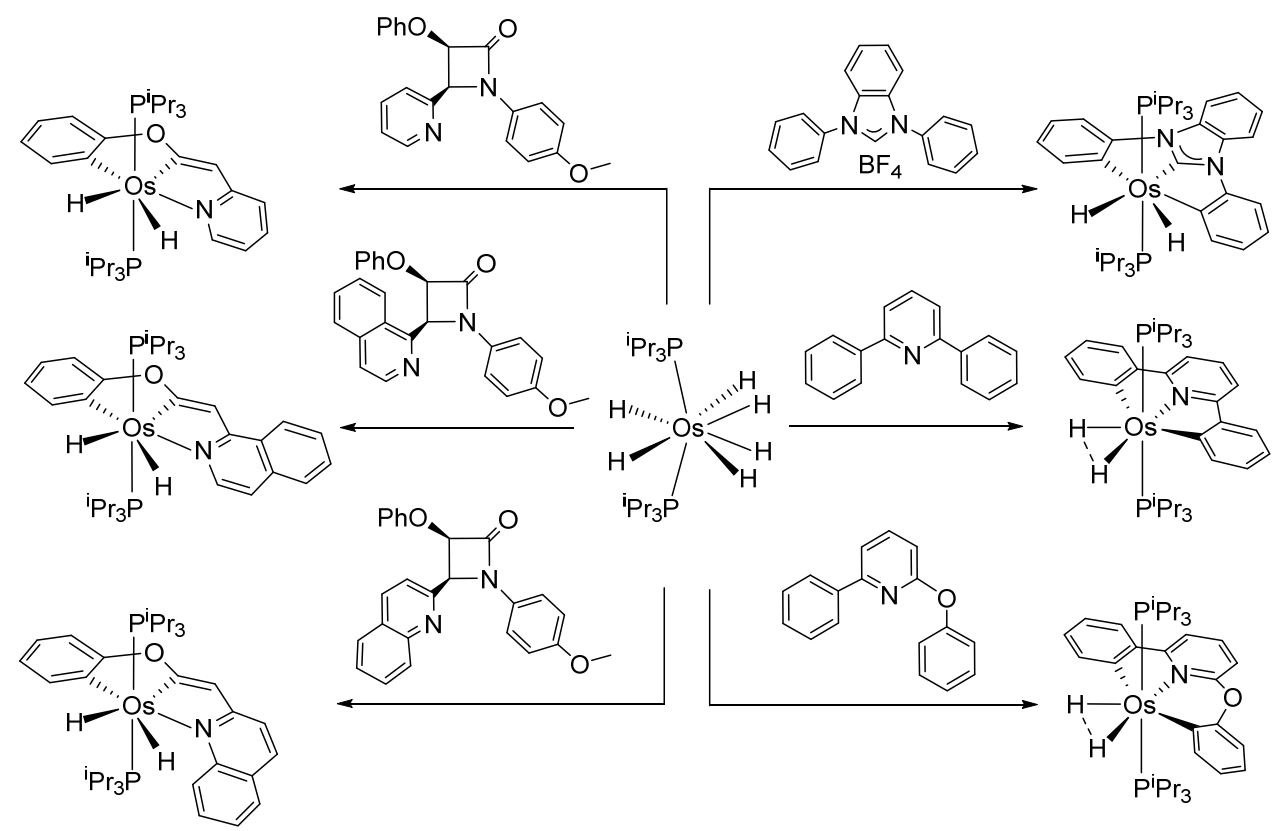

Scheme 1. Osmium Complexes Containing Dianionic C,C',N-, C,C',C-, C,N,C-, and C,N,C'-Pincer Ligands.

derivatives, which display nearly unitary emission quantum yield in some cases (Chart 1$)^{8}$

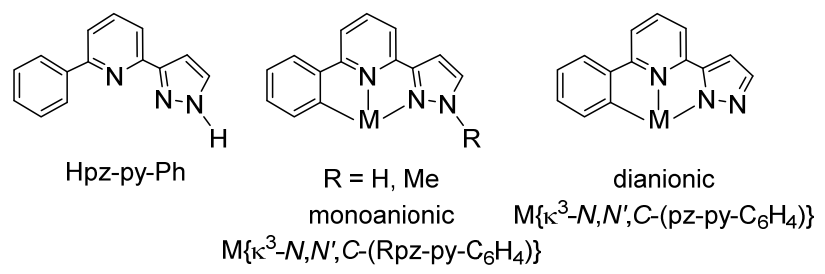

Chart 1. Monoanionic and Dianionic C,N,N-pincer Ligands Derived from 2-phenyl-6-(1H-pyrazol-3-yl)pyridine (Hpz-pyph).

The chemistry of osmium compounds bearing pincer ligands is significantly less developed than those of iridium and platinum. The reported complexes mainly contain neutral ${ }^{9}$ or monoanionic ligands. ${ }^{10}$ The species with dianionic ligands are limited to a few examples. ${ }^{11} \mathrm{We}$ have recently shown that the $\mathrm{d}^{2}$-hexahydride $\mathrm{OsH}_{6}\left(\mathrm{P}^{\mathrm{i}} \mathrm{Pr}_{3}\right)_{2}$ degrades 2-azetidinones substituted at 4-position with an $\mathrm{N}$-heterocycle and at 3-position with a phenoxy group to generate dianionic $\mathrm{C}, \mathrm{C}^{\prime}, \mathrm{N}$-pincer ligands. ${ }^{12}$ This hexahydride also promotes the metalation of the benzimidazolium group and the ortho- $\mathrm{CH}$ bond activation of both phenyl substituents of the cation N,N'diphenylbenzimidazolium ${ }^{13}$ and the double $\mathrm{C}-\mathrm{H}$ bond activation of 2,6-diphenylpyridine and 2-phenoxy-6phenylpyridine $^{14}$ to give complexes containing dianionic $\mathrm{C}, \mathrm{C}^{\prime}, \mathrm{C}-, \mathrm{C}, \mathrm{N}, \mathrm{C}-$, and $\mathrm{C}, \mathrm{N}, \mathrm{C}^{\prime}$-pincer ligands, respectively (Scheme 1). In addition, the hexahydride complex has proved to be an excellent starting material to perform chelate supported $\mathrm{C}-\mathrm{H}^{15}$ and $\mathrm{N}-\mathrm{H}^{16}$ bond activation reactions, in agreement with the trend of polyhydrides of platinum group metals to activate $\sigma$-bonds. ${ }^{17}$

The above mentioned precedents prompted us to investigate the reactions of $\mathrm{OsH}_{6}\left(\mathrm{P}^{\mathrm{i}} \mathrm{Pr}_{3}\right)_{2}$ with 2-phenyl-6-(1H-pyrazol-3- yl)pyridine in the search for stable phosphorescent osmium(IV) emitters with high quantum yields. During this study, we have discovered the unprecedented oxidative addition of the $\mathrm{C}-\mathrm{H}$ bond at 4 position of the pyrazolyl substituent of the pyridine. This paper describes the preparation of stable osmium(IV) complexes containing dianionic and monoanionic $\mathrm{N}, \mathrm{N}^{\prime}, \mathrm{C}$ - and C,N,C'-pincer ligands; analyzes the influence of the phenyl substituent at 2 position of the pyridine on the $\mathrm{C}-\mathrm{H}$ bond activation of the pyrazolyl substituent at the 6 position; and reports the emissive properties of the new compounds, which in some cases reach quantum yields up to 10 times the values previously reported for osmium(IV) derivatives.

\section{RESULTS AND DISCUSSION}

$\mathrm{C}-\mathrm{H}$ and N-H Bond Activation of 2-phenyl-6-(1Hpyrazol-3-yl)pyridine: Dianionic and Monoanionic N,N',CPincer Ligands. The hexahydride complex $\mathrm{OsH}_{6}\left(\mathrm{P}^{\mathrm{i}} \mathrm{Pr}_{3}\right)_{2}$ (1) promotes the activation of a bond of both substituents of 2phenyl-6-(1H-pyrazol-3-yl)pyridine: an ortho- $\mathrm{CH}$ of the phenyl and the pyrazolyl N-H. Thus, the treatment of toluene solutions of 1 with 1.0 equiv of the heterocycle, under reflux, for $2 \mathrm{~h}$ produces the release of molecular hydrogen and the formation of the dihydride-osmium(IV) derivative $\mathrm{OsH}_{2}\left\{\kappa^{3}\right.$ $N, N^{\prime}, C$ - $\left(\right.$ pz-py- $\left.\left.\mathrm{C}_{6} \mathrm{H}_{4}\right)\right\}\left(\mathrm{P}^{\mathrm{i}} \mathrm{Pr}_{3}\right)_{2}$ (2), which was isolated as an orange solid in almost quantitative yield (Scheme 2). 


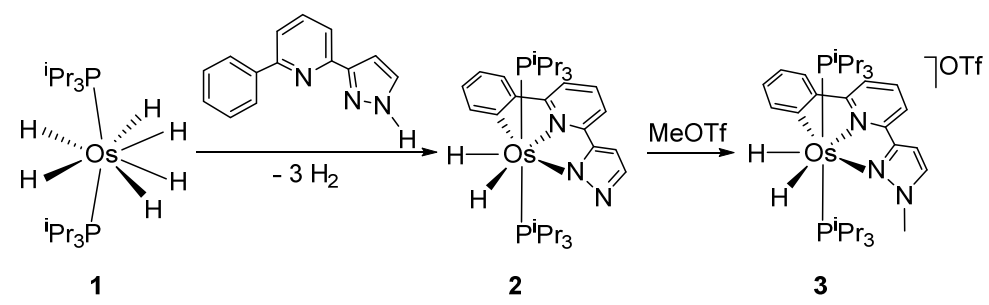

Scheme 2. Formation of Dihydride-osmium(IV) Complexes Containing Dianionic and Monoanionic N,N',C-pincer Ligands.

Complex 2 was characterized by X-ray diffraction analysis. Its structure (Figure 1) proves the formation of the dianionic N,N',C-pincer ligand, which coordinates to the metal center to generate a planar osmapolycyclic system of five fused rings. The greatest deviation from the best plane through the 18 atoms is $0.0359(27)$ and involves to the phenyl $\mathrm{C}(4)$ atom. The coordination geometry around the osmium atom can be described as a distorted pentagonal bipyramid with axial phosphines $\left(\mathrm{P}(1)\right.$-Os- $\left.\mathrm{P}(2)=165.07(3)^{\circ}\right)$. The hydrides, separated by $1.42(3) \AA$, lie in the equatorial plane along with the pincer, which acts with consecutive $\mathrm{C}(1)-\mathrm{Os}-\mathrm{N}(1)$ and $\mathrm{N}(1)-\mathrm{Os}-\mathrm{N}(2)$ angles of $77.03(11)^{\circ}$ and $74.96(9)^{\circ}$, respectively. The Os-C(1) bond length of 2.080(3) $\AA$ compares well with the Os-aryl distance in other five-membered osmacycles resulting from orthometalation reactions, ${ }^{18}$ whereas the Os-py bond length of $2.100(2) \AA(\mathrm{Os}-\mathrm{N}(1))$ is about $0.02 \AA$ shorter than the Os-pz distance of 2.120(2) $\AA$ (Os-N(2)).

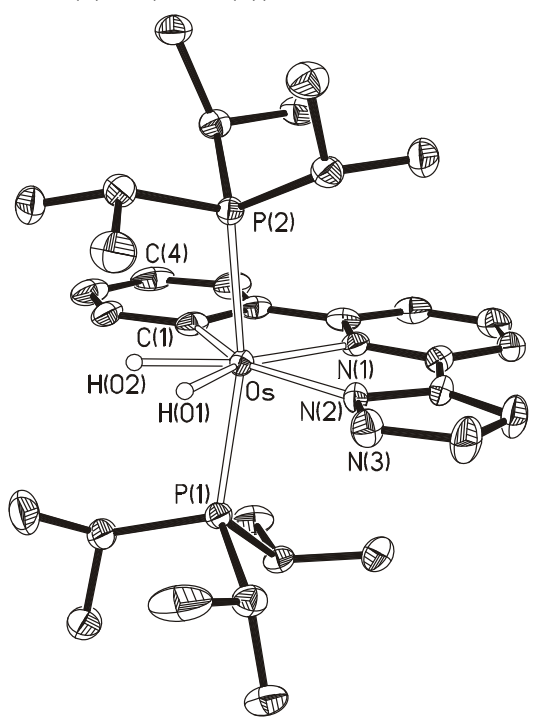

Figure 1. ORTEP diagram of complex 2 (50\% probability ellipsoids). Hydrogen atoms (except $\mathrm{H}(01)$ and $\mathrm{H}(02)$ ) are omitted for clarity. Selected bond lengths $(\AA)$ and angles $(\mathrm{deg})$ : Os-P $(1)=$ $2.3831(8)$, Os- $\mathrm{P}(2)=2.3727(7)$, Os- $\mathrm{N}(1)=2.100(2)$, Os- $\mathrm{N}(2)=$ $2.120(2)$, Os-C(1) = 2.080(3), H(01)-H(02) = 1.42(3); P(1)-Os$\mathrm{P}(2)=165.07(3), \mathrm{C}(1)-\mathrm{Os}-\mathrm{N}(2)=151.99(11), \mathrm{C}(1)-\mathrm{Os}-\mathrm{N}(1)=$ 77.03(11), N(1)-Os-N(2) = 74.96(9).

The ${ }^{31} \mathrm{P}\left\{{ }^{1} \mathrm{H}\right\},{ }^{13} \mathrm{C}\left\{{ }^{1} \mathrm{H}\right\}$, and ${ }^{1} \mathrm{H}$ NMR spectra, in dichloromethane- $d_{2}$, at room temperature are consistent with Figure 1. The ${ }^{31} \mathrm{P}\left\{{ }^{1} \mathrm{H}\right\}$ NMR spectrum shows a singlet at $0.6 \mathrm{ppm}$, as expected for equivalent phosphines. In the ${ }^{13} \mathrm{C}\left\{{ }^{1} \mathrm{H}\right\} \mathrm{NMR}$ spectrum the resonance corresponding to the metalated carbon atom of the phenyl substituent of the pyridine appears at 168.2 ppm as a triplet with a C-P coupling constant of $6.0 \mathrm{~Hz}$. In the
${ }^{1} \mathrm{H}$ NMR spectrum, the inequivalent hydrides give rise to two resonances at -5.05 and $-7.07 \mathrm{ppm}$, which display a $400 \mathrm{MHz}$ $T_{1}(\mathrm{~min})$ of $86 \pm 1 \mathrm{~ms}$ at $213 \mathrm{~K}$. This value fits with a $\mathrm{H}-\mathrm{H}$ separation of $1.47 \AA{ }^{19}$ which agrees well with that obtained from the X-ray diffraction analysis and the calculated one $(1.543 \AA)$ in the DFT-optimized structure (B3LYP(GD3)//SDD(f)/6-31G**) and confirms the compressed dihydride nature of 2 . The hydride resonances are temperature-dependent, increasing the observed $\mathrm{H}-\mathrm{H}$ coupling constant $\left(J_{\text {obs }}\right)$ as the temperature increases from $45.0 \mathrm{~Hz}$ at $193 \mathrm{~K}$ to $54.7 \mathrm{~Hz}$ at $273 \mathrm{~K}$. This dependence can be readily explained in terms of quantum mechanical exchange coupling between the hydride ligands. ${ }^{20}$ The phenomenon has been analyzed according to eq $1,{ }^{17}$ yielding the following parameters: ${ }^{21} J_{\text {mag }}=43 \mathrm{~Hz}, \lambda=0.9 \AA$, and $v=626 \mathrm{~cm}^{-1}$.

$$
J_{\mathrm{obs}}=J_{\text {mag }}+2\left[\left(\frac{v a}{\pi \lambda \operatorname{coth}[h v / 2 k T]}\right) \exp \left\{\frac{-2 \pi^{2} m v\left(a^{2}+\lambda^{2}\right)}{h \operatorname{coth}[h v / 2 k T]}\right\}\right] \text { (1) }
$$

The dianionic N,N',C-pincer ligand of $\mathbf{2}$ can be transformed in a monoanionic counterpart by methylation of the free $\mathrm{N}$ atom. At room temperature, the addition of 1.1 equiv of methyl trifluoromethanesulfonate (MeOTf) to diethyl ether solutions of 2 leads to the salt $\left[\mathrm{OsH}_{2}\left\{\kappa^{3}-N, N^{\prime}, C\right.\right.$-(Mepz-py$\left.\left.\left.\mathrm{C}_{6} \mathrm{H}_{4}\right)\right\}\left(\mathrm{P}^{\mathrm{i}} \mathrm{Pr}_{3}\right)_{2}\right] \mathrm{OTf}(\mathbf{3})$, which was isolated as a yellow solid in $90 \%$ yield. The ${ }^{31} \mathrm{P}\left\{{ }^{1} \mathrm{H}\right\},{ }^{13} \mathrm{C}\left\{{ }^{1} \mathrm{H}\right\},{ }^{19} \mathrm{~F}\left\{{ }^{1} \mathrm{H}\right\}$, and ${ }^{1} \mathrm{H}$ NMR spectra of the obtained solid in dichloromethane- $d_{2}$ support the formation of the salt. The ${ }^{31} \mathrm{P}\left\{{ }^{1} \mathrm{H}\right\}$ NMR spectrum shows a singlet at $-2.2 \mathrm{ppm}$ for the equivalent phosphines. In the ${ }^{13} \mathrm{C}\left\{{ }^{1} \mathrm{H}\right\}$ NMR spectrum, the resonance due to the metalated carbon atom of the phenyl substituent of the pyridine is observed as a triplet $\left({ }^{2} J_{\mathrm{P}-\mathrm{C}}=6.4 \mathrm{~Hz}\right)$ at $160.7 \mathrm{ppm}$, while the methyl group added to the free $\mathrm{N}$ atom of $\mathbf{2}$ gives rise to a singlet at $42.2 \mathrm{ppm}$. The ${ }^{19} \mathrm{~F}\left\{{ }^{1} \mathrm{H}\right\}$ NMR spectrum shows the expected singlet for the OTf anion at $-78.9 \mathrm{ppm}$. At room temperature, the ${ }^{1} \mathrm{H}$ NMR spectrum shows a singlet at 4.23 ppm for the $\mathrm{N}_{-} \mathrm{CH}_{3}$ group and a broad triplet $\left({ }^{2} J_{\mathrm{H}-\mathrm{P}}=11.0 \mathrm{~Hz}\right)$ at $-6.42 \mathrm{ppm}$ for the hydride ligands, which displays a 400 $\mathrm{MHz} T_{1}(\mathrm{~min})$ of $48 \pm 1 \mathrm{~ms}$ at $203 \mathrm{~K}$. This value allows to calculate a separation between the hydride ligands of $1.31 \AA{ }^{19}$ which is about $0.15 \AA$ shorter than that found in the DFToptimized structure $(1.467 \AA)$ and supports the compressed dihydride character of the cation. Like for $\mathbf{2}$, the dihydride resonance is temperature dependent. Thus, between $233 \mathrm{~K}$ and $183 \mathrm{~K}$, it appears as a well defined $\mathrm{ABX}_{2}$ spin system with an A-B coupling constant decreasing form $491 \mathrm{~Hz}$ at $233 \mathrm{~K}$ to $360 \mathrm{~Hz}$ at $183 \mathrm{~K}$. In this case, the analysis of the quantum mechanical exchange coupling phenomenon according to eq 1 yields the parameters: $J_{\mathrm{mag}}=52 \mathrm{~Hz}, \lambda=0.9 \AA$, and $v=673 \mathrm{~cm}^{-}$ 


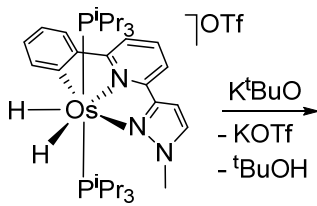

3

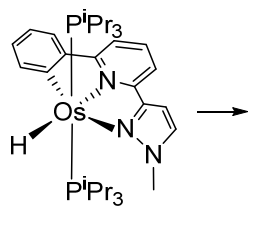

4

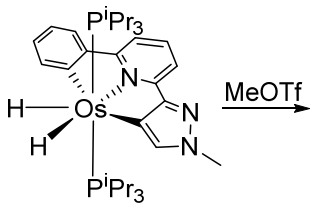

5

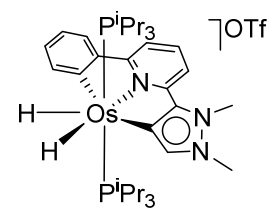

6

Scheme 3. Transformation of C,N,N'- to C,N,C'-pincer Osmium Complexes.

Oxidative Addition of the C-H Bond at 4 Position of the 1-Methylpyrazol-3-yl Group: Dianionic and Monoanionic C,N,C'-Pincer Ligands. Complex $\mathbf{3}$ acts as a Brønsted-Lowry acid. $^{22}$ Its deprotonation produces the reduction of the metal center. Thus, at $0{ }^{\circ} \mathrm{C}$, the addition of 1.2 equiv of $\mathrm{K}^{\mathrm{t}} \mathrm{BuO}$ to tetrahydrofuran solutions of $\mathbf{3}$ gives rise to the osmium(II) monohydride $\mathrm{OsH}\left\{\kappa^{3}-N, N^{\prime}, C\right.$ - $\left.\left(\mathrm{Mepz}-\mathrm{py}-\mathrm{C}_{6} \mathrm{H}_{4}\right)\right\}\left(\mathrm{P}^{\mathrm{i}} \mathrm{Pr}_{3}\right)_{2} \quad$ (4), which was isolated as a brown solid in $75 \%$ yield (Scheme 3 ). Characteristic spectroscopic features of this species are: a triplet $\left({ }^{2} J_{\mathrm{C}-\mathrm{P}}=8.5 \mathrm{~Hz}\right)$ at $170.6 \mathrm{ppm}$, in the ${ }^{13} \mathrm{C}\left\{{ }^{1} \mathrm{H}\right\} \mathrm{NMR}$ spectrum, corresponding to the phenyl metalated carbon atom; a singlet at $9.0 \mathrm{ppm}$ in the ${ }^{31} \mathrm{P}\left\{{ }^{1} \mathrm{H}\right\}$ NMR spectrum, due to the equivalent phosphines; and a triplet $\left({ }^{2} J_{\mathrm{H}-\mathrm{P}}=32.3 \mathrm{~Hz}\right)$ at -9.97 ppm in the ${ }^{1} \mathrm{H}$ NMR spectrum, corresponding to the hydride ligand.

The pincer coordination of the polydentate ligands imposes a trans-C-Os-N angle of about $150^{\circ}$, which strongly deviates of the ideal value of $180^{\circ}$ for an octahedral structure. This produces the destabilization of the oxidation state $2+$ of the metal center, while favors the oxidation state $4+$ with a pentagonal bipyramidal arrangement of ligands. As a consequence, the osmium(II) complex 4 is unstable in solution. At room temperature, in toluene, it evolves into the osmium(IV) species $\mathrm{OsH}_{2}\left\{\kappa^{3}-C, N, C^{\prime}-\left(\mathrm{Mepz}-\mathrm{py}-\mathrm{C}_{6} \mathrm{H}_{4}\right)\right\}\left(\mathrm{P}^{\mathrm{i}} \mathrm{Pr}_{3}\right)_{2} \quad$ (5), in quantitative yield after $6 \mathrm{~h}$. This new compound is the result of the decoordination of the pyrazolyl group of the pincer and the subsequent oxidative addition of the $\mathrm{C}-\mathrm{H}$ bond at position 4 of the five-membered ring. The process gives rise to a change of the pincer ligand from monoanionic $\mathrm{N}, \mathrm{N}^{\prime}, \mathrm{C}$ to dianionic C,N,C'. The transformation was confirmed by X-ray diffraction analysis. Figure 2 shows a view of the molecule. The new pincer ligand imposes the same structural rigidity as the previous one. Thus, its coordination to the metal center generates a planar osmapolycycle of five fused rings similar to that of $\mathbf{2}$. In this case, the greatest deviation from the best plane through the 18 atoms is 0.081 (3) $\AA$ and involves to the phenyl $\mathrm{C}(15)$ atom. The coordination geometry around the osmium atom is the expected pentagonal bipyramid with axial phosphines $\left(\mathrm{P}(1)\right.$-Os- $\left.\mathrm{P}(2)=162.21(3)^{\circ}\right)$. The equatorial plane is formed by the pincer, which acts with $\mathrm{C}(3)-\mathrm{Os}-\mathrm{N}(3)$ and $\mathrm{N}(3)-\mathrm{Os}-\mathrm{C}(11)$ angles of $75.67(11)^{\circ}$ and $75.90(11)^{\circ}$, respectively, and the hydride ligands separated by $1.49(4) \AA$ (1.593 $\AA$ in the DFToptimized structure). The Os-aryl distance of 2.108(3) $\AA$ (Os$\mathrm{C}(11)$ ) is about $0.02 \AA$ longer than that of 2 , whereas the Os$\mathrm{pz}$ bond length of 2.121(3) $\AA$ (Os-C(3)) is about $0.02 \AA$ longer than the Os-aryl distance. In agreement with the presence of equivalent phosphines in the complex, the ${ }^{31} \mathrm{P}\left\{{ }^{1} \mathrm{H}\right\}$ NMR spectrum, in benzene- $d_{6}$, at room temperature shows a singlet at $-0.5 \mathrm{ppm}$. In the ${ }^{13} \mathrm{C}\left\{{ }^{1} \mathrm{H}\right\}$ NMR spectrum, the resonances corresponding to the metalated carbon atoms appear as triplets at $178.8\left({ }^{2} J_{\mathrm{C}-\mathrm{P}}=6.9 \mathrm{~Hz}, \mathrm{Ph}\right)$ and $133.8 \mathrm{ppm}\left({ }^{2} J_{\mathrm{C}-\mathrm{P}}=7.9 \mathrm{~Hz}\right.$, pz). The ${ }^{1} \mathrm{H}$ NMR spectrum shows two doublets of triplets at -
8.48 and -8.69 ppm, with H-H and H-P coupling constants of 13.1 and $14.9 \mathrm{~Hz}$, respectively, due to the inequivalent hydride ligands. These resonances display a $400 \mathrm{MHz} T_{1}(\mathrm{~min})$ of 107 $\pm 1 \mathrm{~ms}$ at $213 \mathrm{~K}$. The value fits with a separation between the hydrides of $1.53 \AA$, which compares well with those obtained by X-ray diffraction analysis and DFT calculations and is consistent with a classical character of the $\mathrm{OsH}_{2}$ unit. In agreement with this, quantum mechanical exchange coupling is not observed in this case.

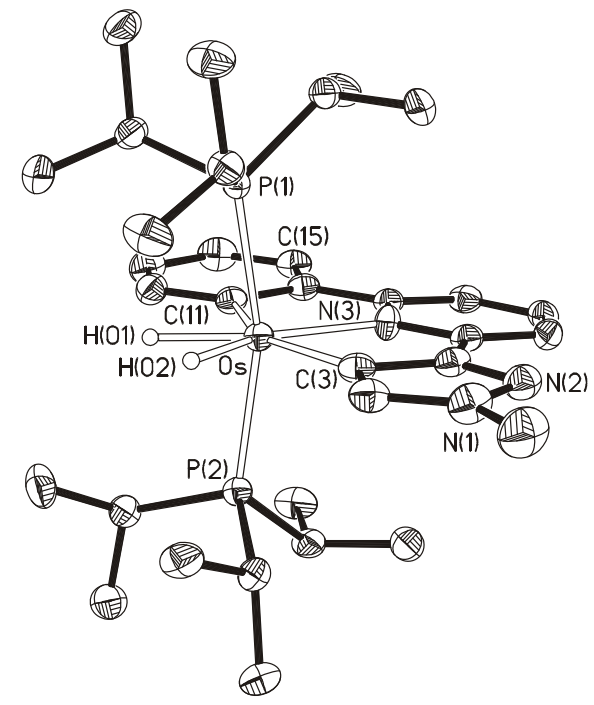

Figure 2. ORTEP diagram of complex 5 (50\% probability ellipsoids). Hydrogen atoms (except $\mathrm{H}(01)$ and $\mathrm{H}(02)$ ) are omitted for clarity. Selected bond lengths $(\AA)$ and angles $(\mathrm{deg})$ : Os-P $(1)=$ $2.3589(8)$, Os- $\mathrm{P}(2)=2.3683(8)$, Os- $\mathrm{N}(3)=2.134(2)$, Os- $\mathrm{C}(3)=$ $2.121(3)$, Os- $\mathrm{C}(11)=2.108(3), \mathrm{H}(01)-\mathrm{H}(02)=1.49(4)$; $\mathrm{P}(1)$-Os$\mathrm{P}(2)=162.21(3), \mathrm{C}(11)-\mathrm{Os}-\mathrm{C}(3)=151.55(12), \mathrm{C}(11)-\mathrm{Os}-\mathrm{N}(3)=$ $75.90(11)$; N(3)-Os-C(3) = 75.67(11).

The transformation of $\mathbf{4}$ into $\mathbf{5}$ was followed by ${ }^{1} \mathrm{H}$ NMR spectroscopy between $290 \mathrm{~K}$ and $330 \mathrm{~K}$. As shown in Figure 3 for the transformation at $290 \mathrm{~K}$, the decrease of 4 with the corresponding increase of $\mathbf{5}$ is an exponential function of the time, in agreement with a first-order process. The activation parameters obtained from the Eyring analysis (Figure 4) are $\Delta H^{\ddagger}=21 \pm 1 \mathrm{kcal} \cdot \mathrm{mol}^{-1}$ and $\Delta S^{\ddagger}=-6 \pm 4 \mathrm{cal} \cdot \mathrm{mol}^{-1} \cdot \mathrm{K}^{-1}$. The slightly negative value of the activation entropy is consistent with an intramolecular process where the oxidative addition of the $\mathrm{C}-\mathrm{H}$ bond is the rate determining step. 


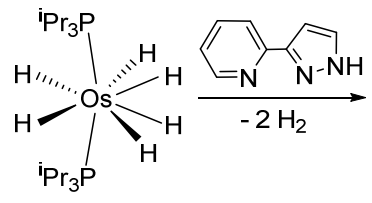

1

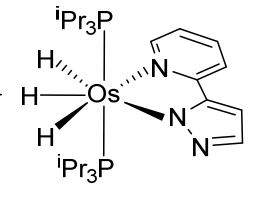

7

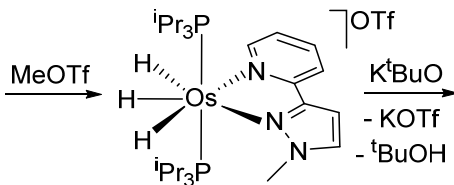

8

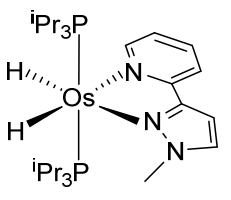

9

Scheme 4. Reaction of 1 with 2-(1H-pyrazol-3-yl)pyridine.

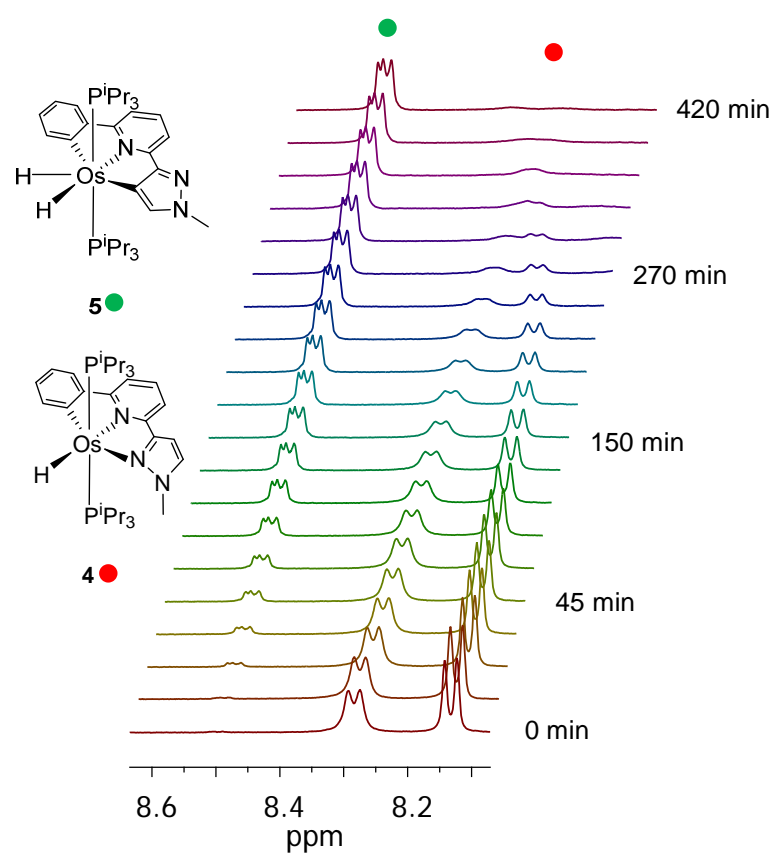

Figure 3. Stacked ${ }^{1} \mathrm{H}$ NMR (partial view of the aromatic region) spectra illustrating the transformation from 4 into 5 in $\mathrm{C}_{6} \mathrm{D}_{6}$ at 290 K.

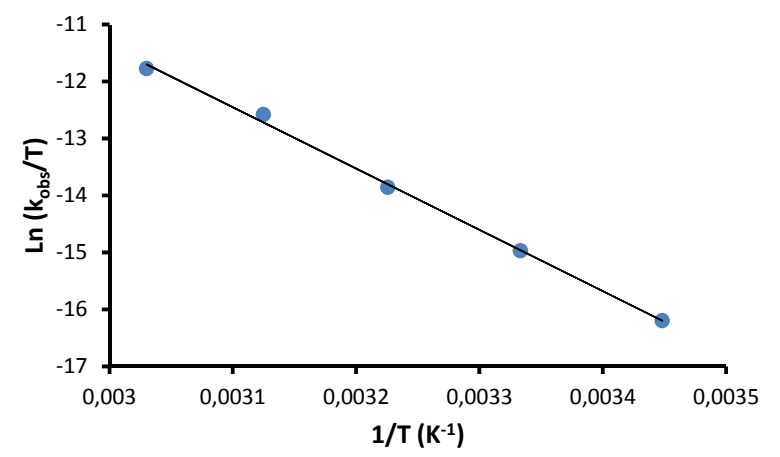

Figure 4. Eyring plot of $k_{\mathrm{obs}}$ for the transformation from $\mathbf{4}$ into 5 .

Complexes containing C-4-donor pyrazolyl groups are very rare. $^{23}$ They have been prepared by ruthenium promoted cyclization of alkynyl(tosyl)hydrazone, ${ }^{24}$ gold-mediated triazoleyne 5-endo-dig cyclization, ${ }^{25}$ and reaction between $\left[\mathrm{AuCl}_{4}\right]$ and 1-phenylpyrazole. ${ }^{26}$

The dianionic C,N,C'-pincer ligand of $\mathbf{5}$ can be transformed in monoanionic by the same procedure as the dianionic N,N',C-pincer ligand of 2, i.e., by methylation of the free $\mathrm{N}$ atom of the five membered ring with MeOTf in diethyl ether, at room temperature. The addition of the methyl group to the free $\mathrm{N}$ atom converts to the pyrazolyl moiety of the pincer into a remote $\mathrm{N}$-heterocyclic carbene. The pyrazole-based remote NHC ligands previously reported are monodentate ${ }^{27}$ the generated ligand in the complex $\left[\mathrm{OsH}_{2}\left\{\kappa^{3}-C, N, C^{\prime}-\left(\mathrm{Me}_{2}\right.\right.\right.$ pz-py$\left.\left.\left.\mathrm{C}_{6} \mathrm{H}_{4}\right)\right\}\left(\mathrm{P}^{\mathrm{P}} \mathrm{Pr}_{3}\right)_{2}\right] \mathrm{OTf}(\mathbf{6})$ is the first pincer bearing a pyrazolebased remote NHC unit. Salt $\mathbf{6}$ was isolated as a red solid in $85 \%$ yield. In agreement with the structure proposed for the cation in Scheme 3, the ${ }^{31} \mathrm{P}\left\{{ }^{1} \mathrm{H}\right\}$ NMR spectrum, in dichloromethane- $d_{2}$, at room temperature shows a singlet at $-0.3 \mathrm{ppm}$ due to the equivalent phosphines. In the ${ }^{13} \mathrm{C}\left\{{ }^{1} \mathrm{H}\right\}$ NMR spectrum, the metalated carbon atoms of the pincer give rise to triplets at $177.2\left({ }^{2} J_{\mathrm{P}-\mathrm{C}}=7.1 \mathrm{~Hz}, \mathrm{Ph}\right)$ and $141.0 \mathrm{ppm}\left({ }^{2} J_{\mathrm{P}-\mathrm{C}}=6.9\right.$ $\mathrm{Hz}, \mathrm{pz}$ ), whereas the resonances corresponding to the $\mathrm{N}_{-} \mathrm{CH}_{3}$ groups are observed as singlets at 37.5 and $35.7 \mathrm{ppm}$. Like for 3, the ${ }^{19} \mathrm{~F}\left\{{ }^{1} \mathrm{H}\right\}$ NMR spectrum contains a singlet at $-78.9 \mathrm{ppm}$ due to the anion of the salt. In the ${ }^{1} \mathrm{H}$ NMR spectrum, the N$\mathrm{CH}_{3}$ resonances are observed at 4.45 and $4.19 \mathrm{ppm}$ as singlets, whereas in the high field region the hydride resonances appear as doublets of triplets at -7.92 and -8.41 ppm with $\mathrm{H}-\mathrm{H}$ and $\mathrm{H}-$ $\mathrm{P}$ coupling constants of 17.6 and $15.1 \mathrm{~Hz}$, respectively. These resonances display a $400 \mathrm{MHz} T_{1}(\mathrm{~min})$ value of $105 \pm 2 \mathrm{~ms}$ at $233 \mathrm{~K}$, which allows to calculate a separation between the hydride signals of $1.53 \AA .^{19}$ This distance agrees well with that obtained from the DFT-optimized structure, $1.556 \AA$, and suggests that the cation is a classical dihydride. Quantum mechanical exchange coupling is not observed in this case.

Influence of the Phenyl Substituent in the $N, N$ ', C to C,N,C'-Pincer Transformation: Complexes Derived from 2-(1H-pyrazol-3-yl)pyridine. The transformation of the pincer from N,N',C to C,N,C' appears to be a consequence of the presence of the metalated phenyl group, which enforces a second L-M-L angle close to the ideal value in a pentagonal bipyramidal structure, typical for osmium(IV) complexes. In order to confirm this, we repeated the reaction sequence collected in Schemes 2 and 3 using 2-(1H-pyrazol-3-yl)pyridine instead of 2-phenyl-6-( $1 H$-pyrazol-3-yl)pyridine (Scheme 4$){ }^{28}$

Treatment of toluene solutions of 1 with 1.0 equiv of 2-( $1 \mathrm{H}$ pyrazol-3-yl)pyridine, under reflux, for $1.5 \mathrm{~h}$ leads to the osmium(IV)-trihydride derivative $\mathrm{OsH}_{3}\left\{\kappa^{2}-N, N\right.$-(pz-py) $\}\left(\mathrm{P}^{\mathrm{i}} \mathrm{Pr}_{3}\right)_{2}$ (7), as a result of the release of $\mathrm{H}_{2}$ and the N-H bond activation of the pyrazolyl substituent of the pyridine. Complex 7 was isolated as a yellow solid in $85 \%$ yield and characterized by X-ray diffraction analysis. The structure has three chemically equivalent but crystallographically independent molecules in the asymmetric unit. Figure 5 shows a drawing of one of them. The geometry around the osmium atom can be rationalized as the expected pentagonal bipyramid with the phosphines occupying axial positions $(\mathrm{P}(1)-\mathrm{Os}(1)-\mathrm{P}(2)=$ $168.08(6)^{\circ}, 165.43(6)^{\circ}$, and $\left.167.83(6)^{\circ}\right)$. The metal coordination sphere is completed by the chelate ligand, which acts with 
$\mathrm{N}(1)-\mathrm{Os}(1)-\mathrm{N}(2)$ bite angles of $74.11(19)^{\circ}, 74.7(2)^{\mathrm{o}}$, and $75.31(19)^{\circ}$, and the hydrides. The separation between $\mathrm{H}(01)$ and $\mathrm{H}(02)$ is $1.37(5)$, whereas $\mathrm{H}(02)$ and $\mathrm{H}(03)$ are separated by $1.73(5) \AA$. According to these values, the complex should be described as a hydride-compressed dihydride. Nevertheless, the DFT-optimized structure suggests a classical character for the $\mathrm{OsH}_{3}$ unit with separations between the hydride ligands of 1.576 and $1.675 \AA$. The ${ }^{31} \mathrm{P}\left\{{ }^{1} \mathrm{H}\right\}$ and ${ }^{1} \mathrm{H}$ NMR spectra in toluene- $d_{8}$ are consistent with the structure shown in Figure 5. The ${ }^{31} \mathrm{P}\left\{{ }^{1} \mathrm{H}\right\}$ NMR spectrum shows a singlet at $15.7 \mathrm{ppm}$ for the equivalent phosphines. In the ${ }^{1} \mathrm{H}$ NMR spectrum at room temperature, the most noticeable feature is a triplet $\left({ }^{2} J_{\mathrm{H}-\mathrm{P}}=\right.$ $12.5 \mathrm{~Hz}$ ) at $-10.53 \mathrm{ppm}$, which indicates the operation of two thermally activated site exchange processes for the inequivalent hydride ligands. Decoalescence occurs at about $233 \mathrm{~K}$ and, between $223 \mathrm{~K}$ and $183 \mathrm{~K}$, two signals are observed. In the range of studied temperatures, a second decoalescence does not take place, suggesting that the exchange processes have very different activation energies. At $218 \mathrm{~K}$, the hydride signal display a $400 \mathrm{MHz} T_{1}(\mathrm{~min})$ of $106 \pm 5 \mathrm{~ms}$, which is consistent with the classical nature of the $\mathrm{OsH}_{3}$ unit.

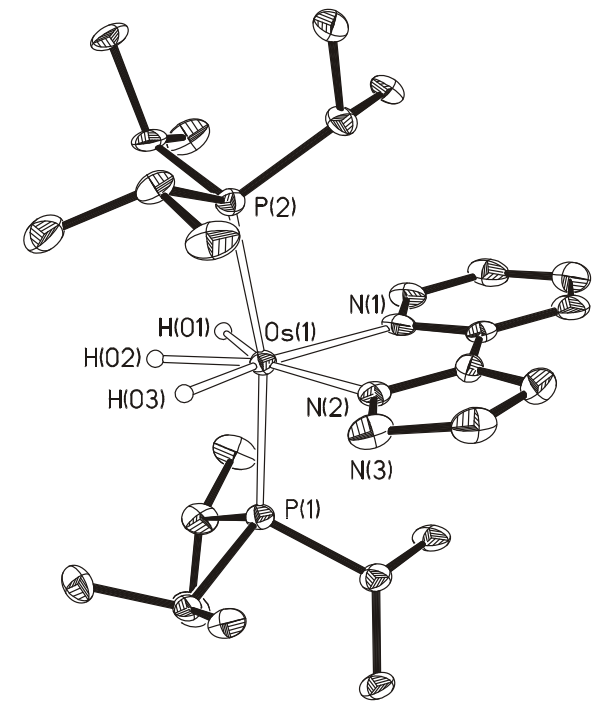

Figure 5. ORTEP diagram of complex 7 (50\% probability ellipsoids). Hydrogen atoms (except the hydrides) are omitted for clarity. Selected bond lengths $(\AA)$ and angles (deg): Os(1)-P(1) = 2.3513(16), 2.3465(16), 2.3513(16), Os(1)-P(2) = 2.3529(16), $2.3541(17), \quad 2.3541(17), \quad$ Os(1)-N(1) = 1.177(5), 1.176(5), 2.169(5), Os- $\mathrm{N}(2)=2.133(5), 2.120(5), 2.127(5), \mathrm{H}(01)-\mathrm{H}(02)=$ $1.37(5), \mathrm{H}(01)-\mathrm{H}(03)=1.73(5) ; \mathrm{P}(1)-\mathrm{Os}(1)-\mathrm{P}(2)=168.08(6)$, 165.43(6), 167.83(6), $\mathrm{N}(1)-\mathrm{Os}(1)-\mathrm{N}(2)=74.11(19), 74.7(2)$, $75.31(19)^{\circ}$.

Complex 7 reacts in a form similar to $\mathbf{2}$. At room temperature, the addition of 1.1 equiv of MeOTf to diethyl ether solutions of 7 produces the precipitation of the salt $\left[\mathrm{OsH}_{3}\left\{\kappa^{2}-N, N\right.\right.$ (Mepz-py) $\}\left(\mathrm{P}^{\mathrm{i}} \mathrm{Pr}_{3}\right)_{2}$ ]OTf (8), as a result of the methylation of the free $\mathrm{N}$ atom of the pyrazolate group. This compound was isolated as a yellow solid in $92 \%$ yield. The equivalent phosphines give rise to a singlet at $17.5 \mathrm{ppm}$, in the ${ }^{31} \mathrm{P}\left\{{ }^{1} \mathrm{H}\right\}$ NMR spectrum. The ${ }^{13} \mathrm{C}\left\{{ }^{1} \mathrm{H}\right\}$ NMR spectrum shows the resonance due to the added methyl group at $42.2 \mathrm{ppm}$, as a singlet. The ${ }^{19} \mathrm{~F}\left\{{ }^{1} \mathrm{H}\right\}$ NMR spectrum contains the expected signal corresponding to the anion at $-79.1 \mathrm{ppm}$. The ${ }^{1} \mathrm{H}$ NMR spectrum shows the $\mathrm{N}-\mathrm{CH}_{3}$ resonance at $4.24 \mathrm{ppm}$, whereas the inequivalent hydrides give rise to a triplet $\left({ }^{2} J_{\mathrm{H}-\mathrm{P}}=12.5 \mathrm{~Hz}\right)$ at -11.02 ppm as for 7. However, in this case, decoalescence is not observed. The hydride resonance displays a $400 \mathrm{MHz} T_{1}(\min )$ of $108 \pm 5 \mathrm{~ms}$ at $218 \mathrm{~K}$, which suggests a classical hydride character for the cation. In agreement with this, the DFToptimized structure reveals that the separations between the hydride ligands are 1.556 and $1.603 \AA$.

Cation $\mathbf{8}$ is a Brønsted-Lowry acid as that of 3. Thus, at room temperature, the treatment of tetrahydrofuran solutions of 8 with 1.2 equiv of $\mathrm{K}^{\mathrm{t}} \mathrm{BuO}$ leads to the osmium(II)dihydride derivative $\mathrm{OsH}_{2}\left\{\kappa^{2}-N, N-(\mathrm{Mepz}-\mathrm{py})\right\}\left(\mathrm{P}^{\mathrm{i}} \mathrm{Pr}_{3}\right)_{2} \quad$ (9), which was isolated as red solid in $69 \%$ yield. A singlet at 29.8 ppm in the ${ }^{31} \mathrm{P}\left\{{ }^{1} \mathrm{H}\right\}$ NMR spectrum and two double $\left({ }^{2} J_{\mathrm{H}-\mathrm{H}}=\right.$ $2.8)$ triplets $\left({ }^{2} J_{\mathrm{H}-\mathrm{P}}=27.0 \mathrm{~Hz}\right)$ at -15.57 and $-15.99 \mathrm{ppm}$ in the ${ }^{1} \mathrm{H}$ NMR spectrum are characteristic spectroscopic features of this compound. In contrast to the osmium(II) complex $\mathbf{4}$ bearing the N,N',C-pincer ligand, complex 9 is stable in toluene. After $24 \mathrm{~h}$ at $100{ }^{\circ} \mathrm{C}$, it is recovered in almost quantitative yield, confirming that the presence of the metalated phenyl group in $\mathbf{4}$ is a determining factor for the N,N',C to $C, N, C^{\prime}$ transformation of the pincer.

The difference in reactivity between 4 and 9 is a nice example illustrating a characteristic feature of the pincer ligands: "The disposition of the donor atoms allows them to develop a marked ability to form less common coordination polyhedra and favors unusual metal oxidation states". ${ }^{29}$

Photophysical Properties of Complexes 2, 3, 5, 7, and 8 . UV/vis absorption spectra of $0.5-4.9 \cdot 10^{-4} \mathrm{M} 2-$ methyltetrahydrofuran solutions of the dihydride-pincer complexes $\mathbf{2}, \mathbf{3}$, and $\mathbf{5}$ and the trihydride-chelate compounds 7 and $\mathbf{8}$, at room temperature, are collected in Table 1. The spectra of the five complexes are similar, showing two main bands, one of them between 279 and $317 \mathrm{~nm}$ and the other one in the 364$393 \mathrm{~nm}$ range. Time dependent DFT calculations (B3LYP(GD3)//SDD(f)/6-31G**, computed in tetrahydrofuran) indicate that the absorptions of higher energy correspond to ligand centered (LC) transitions mainly involving the pincer $(\mathbf{2}, \mathbf{3}$ and $\mathbf{5})$ or chelate $(\mathbf{7}$ and $\mathbf{8})$ groups, whereas the lower energy absorptions involve mainly metal-to-ligand (pincer or chelate) charge transfer processes, being the contribution of the metal higher in complexes $\mathbf{7}$ and $\mathbf{8}$ than in the pincer derivatives $\mathbf{2}, \mathbf{3}$ and $\mathbf{5}$.

The neutral ${ }^{30}$ complexes $\mathbf{2}, \mathbf{5}$ and $\mathbf{7}$ and the salts ${ }^{31} \mathbf{3}$ and $\mathbf{8}$ are emissive upon photoexcitation in the solid state at room temperature and in 2-methyl tetrahydrofuran at room temperature and at $77 \mathrm{~K}$, displaying bands centered between 550 and $690 \mathrm{~nm}$. Figure 6 depicts the emission spectra, whereas Table 2 collects experimental and calculated wavelengths, lifetimes, and quantum yields. The emissions can be attributed to $\mathrm{S}_{0}-\mathrm{T}_{1}$ charge transfer transitions. In accordance with this, good agreement is observed between the experimental wavelengths and those calculated estimating the difference in energy between the optimized triplet state and the singlet state with the same geometry in vacuum. The lifetimes lie in the range 0.8 $5.8 \mu \mathrm{s}$, whereas the quantum yields, measured in the solid state in a doped polymethyl metacrylate (PMMA) film at 5\% wt., depend upon the pincer or chelate character of the polydentate ligand and the neutral or cationic nature of the complex. 
Table 1. Selected UV/vis Experimental Data, Computed TD-DFT THF Vertical Excitation Energies and their Composition of Complexes 2, 3, 5, 7 and $\mathbf{8}$.

\begin{tabular}{|c|c|c|c|c|c|c|}
\hline Complex & $\begin{array}{l}\lambda \mathrm{nm} \\
(\text { expt) }\end{array}$ & $\varepsilon\left(10^{3} \mathrm{M}^{-1} \mathrm{~cm}^{-1}\right)$ & $\begin{array}{c}\text { Excitation } \\
\text { energy (nm) }\end{array}$ & $\begin{array}{l}\text { Oscillator } \\
\text { strength }\end{array}$ & Transition & $\begin{array}{c}\text { Contribution } \\
\%\end{array}$ \\
\hline \multirow[t]{2}{*}{2} & 314 & 8020 & 316 & 0.1503 & HOMO-2 $\rightarrow$ LUMO & 91 \\
\hline & 378 & 7266 & 370 & 0.0995 & HOMO- $1 \rightarrow$ LUMO & 69 \\
\hline \multirow[t]{3}{*}{3} & 317 & 12700 & 307 & 0.1664 & HOMO-2 $\rightarrow$ LUMO & 93 \\
\hline & 379 & 7231 & 368 & 0.1621 & HOMO- $1 \rightarrow$ LUMO & 51 \\
\hline & & & & & $\mathrm{HOMO} \rightarrow \mathrm{LUMO}+1$ & 38 \\
\hline \multirow[t]{2}{*}{5} & 286 & 9817 & 279 & 0.1762 & HOMO-3 $\rightarrow$ LUMO+1 & 87 \\
\hline & 383 & 7383 & 376 & 0.0975 & HOMO-1 $\rightarrow$ LUMO & 77 \\
\hline \multirow[t]{2}{*}{7} & 302 & 6710 & 301 & 0.2023 & HOMO- $2 \rightarrow$ LUMO & 82 \\
\hline & 364 & 6080 & 370 & 0.0921 & HOMO- $1 \rightarrow$ LUMO & 83 \\
\hline \multirow[t]{3}{*}{8} & 279 & 1680 & 272 & 0.2414 & HOMO-3 $\rightarrow$ LUMO & 47 \\
\hline & & & & & HOMO-2 $\rightarrow$ LUMO & 42 \\
\hline & 393 & 4880 & 394 & 0.1166 & HOMO $\rightarrow$ LUMO & 91 \\
\hline
\end{tabular}

Table 2. Photophysical Properties of Complexes 2, 3, 5, 7 and 8 and Theoretical Computed Emissions.

\begin{tabular}{|c|c|c|c|c|c|c|}
\hline Complex & Calculated emission (nm) & media (T/K) & $\lambda_{\text {em }}(n m)$ & $\lambda_{\text {exc }}(\mathrm{nm})$ & $\tau(\mu \mathrm{s})$ & $\Phi^{\mathrm{a}}$ \\
\hline \multirow[t]{3}{*}{2} & 597 & solid (298) & 590 & 345,490 & 1.5 & 0.59 \\
\hline & & 2-MeTHF (298) & 564 & 348,404 & 2.7 & \\
\hline & & 2-MeTHF (77) & 533,574 & 342,403 & 1.0 & \\
\hline \multirow[t]{3}{*}{3} & 685 & solid (298) & 554 & 322 & 3.4 & 0.16 \\
\hline & & 2-MeTHF (298) & 570 & 314,375 & 3.3 & \\
\hline & & 2-MeTHF (77) & 530,565 & 315,375 & 5.8 & \\
\hline \multirow[t]{3}{*}{5} & 594 & solid (298) & 570,594 & 518 & 1.9 & 0.45 \\
\hline & & 2-MeTHF (298) & 568,597 & 383 & 2.7 & \\
\hline & & 2-MeTHF (77) & 548,592 & 384 & 0.9 & \\
\hline \multirow[t]{3}{*}{7} & 605 & solid (298) & 578 & 473 & 3.1 & 0.20 \\
\hline & & 2-MeTHF (298) & 620 & 374 & 0.8 & \\
\hline & & 2-MeTHF (77) & 562 & 348,397 & 2.6 & \\
\hline \multirow[t]{3}{*}{8} & 685 & solid (298) & 553 & 433 & 5.0 & 0.08 \\
\hline & & 2-MeTHF (298) & 660 & 390 & 2.7 & \\
\hline & & 2-MeTHF (77) & 566 & 396 & 3.0 & \\
\hline
\end{tabular}

${ }^{a}$ Measurements in solid state in a doped PMMA film at $5 \%$ wt..

The denticity of the polydentate ligand has a poor influence on the color. However, it is determining for the quantum yield. Neutral compounds $\mathbf{2}$ and $\mathbf{5}$ bearing a pincer ligand reach quantum yields that are thrice and twice, respectively, the quantum yield of 7 , containing the chelate pz-py group. The quantum yield of the pincer salt $\mathbf{3}$ is also double than that of the salt 8 bearing pz-py. In this context it should be highlighted that the quantum yield of $\mathbf{2}$ is about 10 times the highest quantum yield reported until now for Os(IV) complexes. This unusual result can be related to the molecular rigidity imposed by the pincer, which reduces the energy dissipation by means of dynamic processes. In this respect, the presence of a methyl group at one of the $\mathrm{N}$ atoms of $\mathbf{5}$ can explain why its quantum yield is lower than that of $\mathbf{2}$. The salts $\mathbf{3}$ and $\mathbf{8}$ display quantum yields noticeably lower than their neutral counterparts. Cationic charge increases the non-classical interactions in the $\mathrm{OsH}_{n}$ units, ${ }^{32}$ which facilitates the motion of the hydride ligands and therefore the energy dissipation.

A noticeable feature revealed by the spectra of Figure 6 is that the rigidity imposed by the pincer gives rise to narrower emissions. This, which is highly desirable for OLED display application, could be related to a less pronounced difference between excited state structure and ground state structure. ${ }^{33} \mathrm{~A}$ similar effect was observed when the emission spectra of the complexes Os $\left\{\kappa^{4}-C, C, C, C\right.$ - $\left(\mathrm{C}_{6} \mathrm{H}_{4}\right.$-BzIm- $\mathrm{CH}_{2} \mathrm{CH}_{2}$-BzIm$\left.\left.\mathrm{C}_{6} \mathrm{H}_{4}\right)\right\}(\mathrm{dppbz})(\mathrm{dppbz}=1,2$-bis(diphenylphosphino)benzene) and $\mathrm{Os}\left\{\kappa^{2}-C, C \text { - }\left(\mathrm{MeBzIm}-\mathrm{C}_{6} \mathrm{H}_{4}\right)\right\}_{2}(\mathrm{dppbz})$ were compared. The rigidity imposed by the linker $\mathrm{CH}_{2} \mathrm{CH}_{2}$ in the tetradentate ligand gives rise to an emission spectrum for the first of them narrower than that for the second one bearing two free BzIm$\mathrm{C}_{6} \mathrm{H}_{4}$ groups. ${ }^{\mathrm{i}}$ 

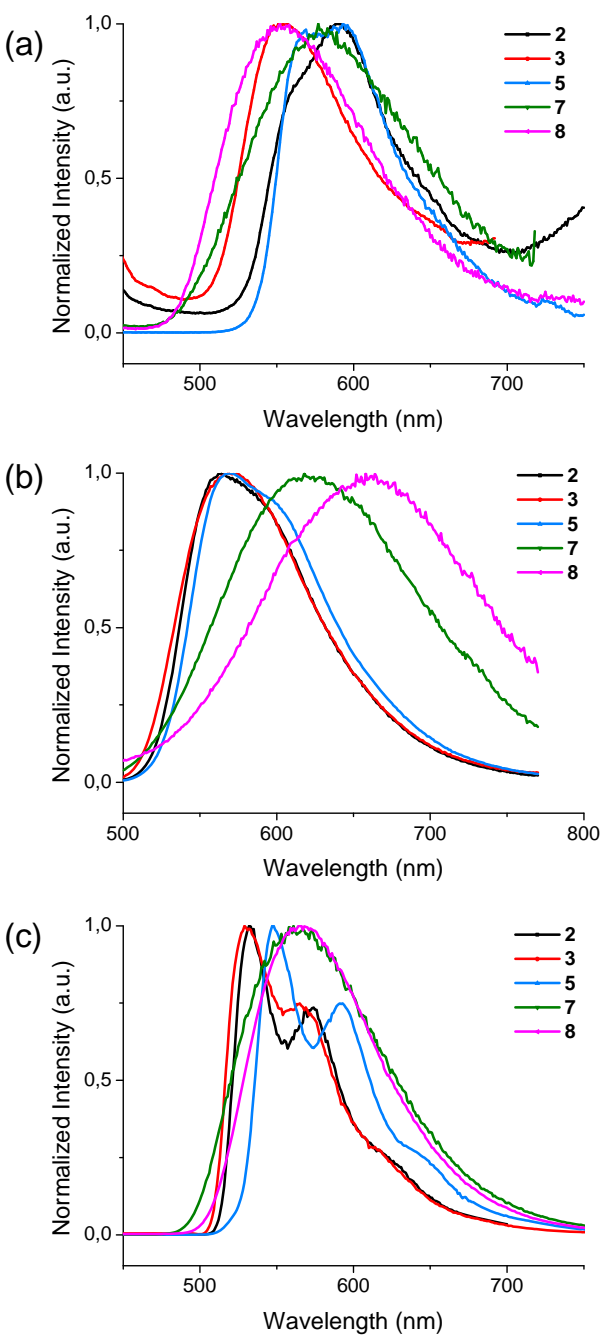

Figure 6. Emission spectra in the solid state at $298 \mathrm{~K}$ (a), 2MeTHF at $298 \mathrm{~K}$ (b) and in 2-MeTHF at $77 \mathrm{~K}$ (c) for complexes $\mathbf{2}, \mathbf{3}, \mathbf{5}, \mathbf{7}$ and $\mathbf{8}$.

The spectra of pincer complexes $\mathbf{2}, \mathbf{3}$, and $\mathbf{5}$ in 2methyltetrahydrofuran at $77 \mathrm{~K}$ shows that the emission is split into two bands, under these conditions. This is consistent with a change of the dominant character of the excited state from MLCT to ligand-centered $\pi-\pi^{*}$.

\section{CONCLUDING REMARKS}

This study has revealed that the hexahydride $\mathrm{OsH}_{6}\left(\mathrm{P}^{\mathrm{i}} \mathrm{Pr}_{3}\right)_{2}$ promotes the simultaneous activation of the ortho- $\mathrm{CH}$ bond of the phenyl substituent and the $\mathrm{N}-\mathrm{H}$ bond of the pyrazolyl group of 2-phenyl-6-(1H-pyrazol-3-yl)pyridine. This process is the key to generate four different types of pincer ligands, which stabilize pentagonal bipyramidal osmium(IV) complexes proving that the disposition of donor atoms of pincer ligands allows them to form less common coordination polyhedra and to favor unusual metal oxidation states. Initially, a dianionic N,N',C-pincer is obtained, which is converted in monoanionic by methylation of the free $\mathrm{N}$ atom of the pyrazolyl group. The deprotonation of the resulting salt gives rise to the transformation of the latter into a dianionic $\mathrm{C}, \mathrm{N}, \mathrm{C}^{\prime}-$ pincer by oxidative addition of the $\mathrm{C}-\mathrm{H}$ bond at position 4 of the pyrazolyl group to the metal center of an osmium(II) intermediate. The presence of a metalated phenyl group in the corner of the monoanionic N,N',C-pincer of this intermediate is the leading factor for the oxidative addition. The methylation of the free $\mathrm{N}$ atom of the new five-membered heteroring converts the dianionic $\mathrm{C}, \mathrm{N}, \mathrm{C}^{\prime}$-pincer into monoanionic, containing a remote $\mathrm{N}$-heterocyclic carbene unit.

Osmium(IV) complexes containing the above mentioned pincer ligands are phosphorescent emitters in the red-green region with quantum yields unusually high for osmium(IV) and narrow emissions. This is consequence of the rigidity imposed by the pincer, which reduces both the energy dissipation by means of dynamic processes and the difference between excited state structure and ground state structure.

In conclusion, pincer ligands forming two consecutive fivemembered rings form pentagonal bipyramidal osmium(IV) complexes more stable than their octahedral osmium(II) counterparts and the molecular rigidity imposed by the pincer allows phosphorescent osmium(IV) emitters with quantum yields comparable to those of the osmium(II) compounds.

\section{EXPERIMENTAL SECTION}

General Information. All reactions were carried out with rigorous exclusion of air using Schlenk-tube techniques. Solvents were obtained oxygen- and water-free from an MBraun solvent purification apparatus. ${ }^{1} \mathrm{H},{ }^{31} \mathrm{P}\left\{{ }^{1} \mathrm{H}\right\},{ }^{13} \mathrm{C}\left\{{ }^{1} \mathrm{H}\right\}$ and ${ }^{19} \mathrm{~F}\left\{{ }^{1} \mathrm{H}\right\}$ NMR spectra were recorded on Bruker $300 \mathrm{ARX}$, Bruker Avance $300 \mathrm{MHz}$, and Bruker Avance $400 \mathrm{MHz}$ instruments. Chemical shifts (expressed in parts per million) are referenced to residual solvent peaks $\left({ }^{1} \mathrm{H},{ }^{13} \mathrm{C}\left\{{ }^{1} \mathrm{H}\right\}\right)$, external $85 \% \mathrm{H}_{3} \mathrm{PO}_{4}\left({ }^{31} \mathrm{P}\left\{{ }^{1} \mathrm{H}\right\}\right)$, or external $\mathrm{CFCl}_{3}\left({ }^{19} \mathrm{~F}\left\{{ }^{1} \mathrm{H}\right\}\right)$. Coupling constants $J$ and $N$ are given in hertz. Attenuated total reflection infrared spectra (ATR-IR) of solid samples were run on a Perkin-Elmer Spectrum 100 FT-IR spectrometer. C, H, and N analyses were carried out in a Perkin-Elmer $2400 \mathrm{CHNS} / \mathrm{O}$ analyzer. High-resolution electrospray mass spectra were acquired using a MicroTOF-Q hybrid quadrupole time-of-flight spectrometer (Bruker Daltonics, Bremen, Germany). $\mathrm{OsH}_{6}\left(\mathrm{P}^{\mathrm{i}} \mathrm{Pr}_{3}\right)_{2}{ }^{34}$ and 2-phenyl-6-(1H-pyrazol-3-yl)pyridine ${ }^{7 a}$ were prepared by the published methods.

Photophysical Studies. All the manipulations of the organometallic compounds were carried out in strict absence of oxygen and water. An Evolution 600 spectrophotometer was used to record UV-vis spectra. Steady-state photoluminescence spectra were obtained with a Jobin-Yvon Horiba Fluorolog FL-3-11 spectrofluorometer. An IBH 5000F coaxial nanosecond flash lamp was used to measure the lifetimes. Photoluminescent quantum yield data were measured on a Hamamatsu Quantaurus-QY Absolute PL quantum yield C11347-11 spectrometer.

Reaction of $\mathrm{OsH}_{6}\left(\mathrm{P}^{\mathrm{i}} \mathrm{Pr}_{3}\right)_{2}$ (1) with 2-phenyl-6-(1H-pyrazol-3yl)pyridine: Preparation of $\mathrm{OsH}_{2}\left\{\kappa^{3}-N, N^{\prime}, C-\left(\mathrm{pz}-\mathrm{py}-\mathrm{C}_{6} \mathrm{H}_{4}\right)\right\}\left(\mathrm{P}^{\mathrm{i}} \mathrm{Pr}_{3}\right)_{2}$ (2). A solution of $1(500 \mathrm{mg}, 0.968 \mathrm{mmol})$ in toluene $(7 \mathrm{~mL})$ was treated with 2-phenyl-6-(1H-pyrazol-3-yl)pyridine (214 mg, 0.968 $\mathrm{mmol})$. The resulting mixture was refluxed for $2 \mathrm{~h}$, getting a dark orange solution. After cooling at room temperature the solvent was removed in vacuo, affording a dark orange residue. Addition of methanol $(5 \mathrm{~mL})$ afforded a bright orange solid, which was washed with further portions of methanol $(2 \times 5 \mathrm{~mL})$ and dried in vacuo. Cooling the methanol solution at $-20{ }^{\circ} \mathrm{C}$ afforded a second crop of solid. Yield: $645 \mathrm{mg}(91 \%)$. Anal. calcd. for $\mathrm{C}_{32} \mathrm{H}_{53} \mathrm{~N}_{3} \mathrm{OsP}_{2}$ : C, 52.55; H, 7.30; N, 5.74. Found: C, 52.48; H, 7.40; N, 5.91. HRMS (electrospray, $\mathrm{m} / \mathrm{z}$ ) calcd for $\mathrm{C}_{32} \mathrm{H}_{54} \mathrm{~N}_{3} \mathrm{OsP}_{2}[\mathrm{M}+\mathrm{H}]^{+}$: 734.3404; found: 734.3379. IR (cm $\left.{ }^{1}\right): v(\mathrm{Os}-\mathrm{H}) 2134(\mathrm{w}), v(\mathrm{C}=\mathrm{N}) 1602(\mathrm{~m}), v(\mathrm{C}=\mathrm{C}) 1579(\mathrm{~m}) .{ }^{1} \mathrm{H}$ NMR $\left(400 \mathrm{MHz}, \mathrm{CD}_{2} \mathrm{Cl}_{2}, 298 \mathrm{~K}\right): \delta 7.80\left(\mathrm{~d}, J_{\mathrm{H}-\mathrm{H}}=7.5,1 \mathrm{H}, \mathrm{Ph}\right), 7.67\left(\mathrm{~d}, J_{\mathrm{H}-}\right.$ $\mathrm{H}=7.5,1 \mathrm{H}, \mathrm{Ph}), 7.56\left(\mathrm{~d}, J_{\mathrm{H}-\mathrm{H}}=7.5,1 \mathrm{H}, \mathrm{py}\right), 7.51\left(\mathrm{~d}, J_{\mathrm{H}-\mathrm{H}}=1.8,1 \mathrm{H}\right.$, pz), $7.50\left(\mathrm{t}, J_{\mathrm{H}-\mathrm{H}}=7.5,1 \mathrm{H}, \mathrm{py}\right), 7.30\left(\mathrm{~d}, J_{\mathrm{H}-\mathrm{H}}=7.5,1 \mathrm{H}, \mathrm{py}\right), 6.89(\mathrm{t}$, $\left.J_{\mathrm{H}-\mathrm{H}}=7.5,1 \mathrm{H}, \mathrm{Ph}\right), 6.80\left(\mathrm{t}, J_{\mathrm{H}-\mathrm{H}}=7.5,1 \mathrm{H}, \mathrm{Ph}\right), 6.78\left(\mathrm{~d}, J_{\mathrm{H}-\mathrm{H}}=1.8\right.$, $1 \mathrm{H}, \mathrm{pz}), 1.80\left(\mathrm{~m}, 6 \mathrm{H}, \mathrm{PCH}\left(\mathrm{CH}_{3}\right)_{2}\right), 0.81$ (dvt, $J_{\mathrm{H}-\mathrm{H}}=7.0, N=12.6$, $\left.36 \mathrm{H}, \mathrm{PCH}\left(\mathrm{CH}_{3}\right)_{2}\right),-5.05$ (br, $\left.1 \mathrm{H}, \mathrm{Os}-\mathrm{H}\right),-7.07$ (br, $\left.1 \mathrm{H}, \mathrm{Os}-\mathrm{H}\right)$. 
${ }^{1} \mathrm{H}\left\{{ }^{31} \mathrm{P}\right\}$ NMR (400 MHz, $\mathrm{CD}_{2} \mathrm{Cl}_{2}, 193 \mathrm{~K}$, high field region): $\delta-5.48$ $\left(\mathrm{d}, J_{\mathrm{H}-\mathrm{H}}=45.6,1 \mathrm{H}, \mathrm{Os}-\mathrm{H}\right),-7.17\left(\mathrm{~d},{ }^{2} J_{\mathrm{H}-\mathrm{H}}=45.6,1 \mathrm{H}, \mathrm{Os}-\mathrm{H}\right) .{ }^{13} \mathrm{C}\left\{{ }^{1} \mathrm{H}\right\}$ NMR (100.61 MHz, $\left.\mathrm{CD}_{2} \mathrm{Cl}_{2}, 298 \mathrm{~K}\right): \delta 168.2\left(\mathrm{t},{ }^{2} J_{\mathrm{C}-\mathrm{P}}=6.0\right.$, Os-C), 164.8 (s, C Ph), 154.6 (s, C py), 151.4 (s, C pz), 146.1 (s, CH Ph), 145.8 (s, C py), 140.8 (s, CH pz), 136.1 (s, CH py), 130.1, 125.0, 119.6 (all s, CH Ph), 112.1, 111.8 (both s, CH py), 103.1 (s, CH pz), 26.1 (vt, $\left.N=25.2, \mathrm{PCH}\left(\mathrm{CH}_{3}\right)_{2}\right), 19.4,19.3$ (both s, $\mathrm{PCH}\left(\mathrm{CH}_{3}\right)_{2}$ ). ${ }^{31} \mathrm{P}\left\{{ }^{1} \mathrm{H}\right\}$ NMR $\left(161.98 \mathrm{MHz}, \mathrm{CD}_{2} \mathrm{Cl}_{2}, 298 \mathrm{~K}\right): \delta 0.6(\mathrm{~s}) . T_{1}(\min )(400$ $\left.\mathrm{MHz}, \mathrm{CD}_{2} \mathrm{Cl}_{2}, 213 \mathrm{~K}\right): 86 \pm 1 \mathrm{~ms}(-5.46 \mathrm{ppm}), 86 \pm 1 \mathrm{~ms}(-7.17 \mathrm{ppm})$.

Reaction of $\mathrm{OsH}_{2}\left\{\kappa^{3}-N, N^{\prime}, C\right.$ - $\left.\left(\mathrm{pz}-\mathrm{py}-\mathrm{C}_{6} \mathrm{H}_{4}\right)\right\}\left(\mathrm{P}^{\mathrm{i}} \mathrm{Pr}_{3}\right)_{2}$ (2) with MeOTf: Preparation of $\left[\mathrm{OsH}_{2}\left\{\kappa^{3}-N, N, C\right.\right.$-(Mepz-py$\left.\left.\mathbf{C}_{6} \mathbf{H}_{4}\right)\right\}\left(\mathbf{P}^{\mathrm{i}} \mathbf{P r}_{3}\right)_{2}$ ]OTf (3). A solution of $2(500 \mathrm{mg}, 0.684 \mathrm{mmol})$ in diethyl ether $(5 \mathrm{~mL})$ was treated with MeOTf $(85 \mu \mathrm{L}, 0.752 \mathrm{mmol})$, getting a pale yellow suspension. The yellow solid was decanted, washed with further portions of diethyl ether $(3 \times 4 \mathrm{~mL})$ and dried in vacuo. Yield: $551 \mathrm{mg}(90 \%)$. Anal. calcd. for $\mathrm{C}_{34} \mathrm{H}_{56} \mathrm{~F}_{3} \mathrm{~N}_{3} \mathrm{O}_{3} \mathrm{Os} \mathrm{P}_{2} \mathrm{~S}$ : C, 45.57; H, 6.30; N, 4.69; S, 3.58. Found: C, 45.32; H, 6.25; N, 4.83; S, 4.05. HRMS (electrospray, $m / z$ ) calcd for $\mathrm{C}_{33} \mathrm{H}_{56} \mathrm{~N}_{3} \mathrm{Os} \mathrm{P}_{2}[\mathrm{M}]^{+}$: 748.3560; found: 748.3570. IR $\left(\mathrm{cm}^{-1}\right): v(\mathrm{Os}-\mathrm{H}) 2161(\mathrm{w}), v\left(\mathrm{CF}_{3}\right)$ 1261 (vs), v(SO) 1247, 1143, 1029 (vs). ${ }^{1} \mathrm{H}$ NMR (400 MHz, $\mathrm{CD}_{2} \mathrm{Cl}_{2}$, $298 \mathrm{~K}): \delta 8.05\left(\mathrm{~d}, J_{\mathrm{H}-\mathrm{H}}=2.8,1 \mathrm{H}, \mathrm{pz}\right), 7.86\left(\mathrm{~d}, J_{\mathrm{H}-\mathrm{H}}=7.7,1 \mathrm{H}, \mathrm{py}\right)$, 7.80-7.75 $\left(\mathrm{m}, 3 \mathrm{H}, \mathrm{Ph}\right.$ and py), $7.72\left(\mathrm{~d}, J_{\mathrm{H}-\mathrm{H}}=7.7,1 \mathrm{H}, \mathrm{py}\right), 7.04\left(\mathrm{~d}, J_{\mathrm{H}-}\right.$ $\mathrm{H}=2.8,1 \mathrm{H}, \mathrm{pz}), 7.03\left(\mathrm{t}, J_{\mathrm{H}-\mathrm{H}}=7.6,1 \mathrm{H}, \mathrm{Ph}\right), 6.94\left(\mathrm{t}, J_{\mathrm{H}-\mathrm{H}}=7.6,1 \mathrm{H}\right.$, $\mathrm{Ph}), 4.23\left(\mathrm{~s}, 3 \mathrm{H}, \mathrm{CH}_{3}\right), 1.69\left(\mathrm{~m}, 6 \mathrm{H}, \mathrm{PC}\left(\mathrm{CH}_{3}\right)_{2}\right), 0.85\left(\mathrm{dvt}, J_{\mathrm{H}-\mathrm{H}}=\right.$ $\left.6.8, N=13.2,18 \mathrm{H}, \mathrm{PCH}\left(\mathrm{CH}_{3}\right)_{2}\right), 0.81\left(\mathrm{dvt}, J_{\mathrm{H}-\mathrm{H}}=6.8, N=13.2,18 \mathrm{H}\right.$, $\left.\mathrm{PCH}\left(\mathrm{CH}_{3}\right)_{2}\right),-6.42$ (br t, $\left.{ }^{2} J_{\mathrm{H}-\mathrm{P}}=11.0,2 \mathrm{H}, \mathrm{Os}-\mathrm{H}\right) .{ }^{1} \mathrm{H}\left\{{ }^{31} \mathrm{P}\right\}$ NMR $(400$ $\mathrm{MHz}, \mathrm{CD}_{2} \mathrm{Cl}_{2}, 183 \mathrm{~K}$, high field region): $\delta-6.57$ (AB spin system, $J_{\mathrm{A}-}$ в $=360, \Delta v=445.5,2 \mathrm{H}$, Os- $\mathrm{H}) .{ }^{13} \mathrm{C}\left\{{ }^{1} \mathrm{H}\right\}$ NMR $(100.61 \mathrm{MHz}$, $\left.\mathrm{CD}_{2} \mathrm{Cl}_{2}, 298 \mathrm{~K}\right): \delta 165.5(\mathrm{~s}, \mathrm{C}, \mathrm{Ph}), 160.7\left(\mathrm{t},{ }^{2} J_{\mathrm{C}-\mathrm{P}}=6.4\right.$, Os-C), 154.7 (s, C py), 150.5 (s, C pz), 145.5 (s, CH Ph), 143.7 (s, C py), 138.0 (s, $\mathrm{CH}$ py), 137.2 (s, CH pz), 131.9, 126.3, 122.0 (all s, $\mathrm{CH} \mathrm{Ph),} 121.6$ (q, $\left.{ }^{1} J_{\mathrm{C}-\mathrm{F}}=321.3, \mathrm{CF}_{3} \mathrm{SO}_{3}\right), 116.1,116.0$ (both s, $\mathrm{CH}$ py), 106.8 (s, CH pz), $42.2\left(\mathrm{~s}, \mathrm{NCH}_{3}\right), 27.5$ (vt, $\left.N=25.0, \mathrm{PCH}\left(\mathrm{CH}_{3}\right)_{2}\right), 19.9,19.5$ (both s, $\left.\mathrm{PCH}\left(\mathrm{CH}_{3}\right)_{2}\right) \cdot{ }^{31} \mathrm{P}\left\{{ }^{1} \mathrm{H}\right\}$ NMR $\left(161.98 \mathrm{MHz}, \mathrm{CD}_{2} \mathrm{Cl}_{2}, 298 \mathrm{~K}\right): \delta-2.2$ (s). ${ }^{19} \mathrm{~F}\left\{{ }^{1} \mathrm{H}\right\}$ NMR $\left(282.33 \mathrm{MHz}, \mathrm{CD}_{2} \mathrm{Cl}_{2}, 298 \mathrm{~K}\right): \delta$-78.9. $T_{1}(\mathrm{~min})$ $\left(400 \mathrm{MHz}, \mathrm{CD}_{2} \mathrm{Cl}_{2}, 203 \mathrm{~K}\right): 48 \pm 1 \mathrm{~ms}(-6.57 \mathrm{ppm})$.

Reaction of $\left[\mathrm{OsH}_{2}\left\{\kappa^{3}-N, N^{\prime}, C\right.\right.$-(Mepz-py- $\left.\left.\left.\mathrm{C}_{6} \mathrm{H}_{4}\right)\right\}\left(\mathrm{P}^{\mathrm{i}} \mathrm{Pr}_{3}\right)_{2}\right] \mathrm{OTf}(3)$ with KO ${ }^{t} \mathrm{Bu}$ : Preparation of $\mathrm{OsH}\left\{\kappa^{3}-N, N^{\prime}, C\right.$-(Mepz-py$\left.\left.\mathbf{C}_{6} \mathbf{H}_{4}\right)\right\}\left(\mathbf{P}^{\mathrm{i}} \mathbf{P r}_{3}\right)_{2}$ (4). A solution of $3(417 \mathrm{mg}, 0.465 \mathrm{mmol})$ in THF (5 $\mathrm{mL})$ was treated with $\mathrm{KO}^{\mathrm{t}} \mathrm{Bu}(63 \mathrm{mg}, 0.558 \mathrm{mmol})$ at $0{ }^{\circ} \mathrm{C}$, getting a dark red solution. After stirring for $5 \mathrm{~min}$ at this temperature, the solvent was evaporated to dryness affording a dark red residue. Toluene $(5 \mathrm{~mL})$ was added and the resulting suspension was filtered to afford a brown solution that was dried in vacuo to afford a brown residue. After cooling at $-78{ }^{\circ} \mathrm{C}$, addition of pentane $(4 \mathrm{~mL})$ caused precipitation of a brown solid that was washed with further portions of pentane $(2 \times 4 \mathrm{~mL})$ and dried in vacuo. Yield: $260 \mathrm{mg}(75 \%)$. Anal. calcd. for $\mathrm{C}_{33} \mathrm{H}_{55} \mathrm{~N}_{3} \mathrm{OsP}_{2}$ : C, 53.15; H, 7.43; N, 5.63. Found: $\mathrm{C}$, 52.91; H, 7.63; N, 5.47. HRMS (electrospray, $\mathrm{m} / \mathrm{z}$ ) calcd for $\mathrm{C}_{33} \mathrm{H}_{55} \mathrm{~N}_{3} \mathrm{OsP}_{2}[\mathrm{M}]^{+}:$747.3482; found: 747.3484. IR $\left(\mathrm{cm}^{-1}\right): v(\mathrm{Os}-\mathrm{H})$ 1987 (w). ${ }^{1} \mathrm{H}$ NMR (400 MHz, THF- $\left.d_{8}, 253 \mathrm{~K}\right): \delta 7.74\left(\mathrm{~d}, J_{\mathrm{H}-\mathrm{H}}=2.7\right.$, $1 \mathrm{H}, \mathrm{pz}), 7.68-7.57\left(\mathrm{~m}, 4 \mathrm{H}, \mathrm{Ph}\right.$ and py), $7.10(\mathrm{~m}, 1 \mathrm{H}, \mathrm{py}), 6.98\left(\mathrm{~d}, J_{\mathrm{H}-\mathrm{H}}\right.$ $=2.7,1 \mathrm{H}, \mathrm{pz}), 6.65(\mathrm{~m}, 1 \mathrm{H}, \mathrm{Ph}), 6.59(\mathrm{~m}, 1 \mathrm{H}, \mathrm{Ph}), 4.09\left(\mathrm{~s}, 3 \mathrm{H}, \mathrm{CH}_{3}\right)$, $1.73\left(\mathrm{~m}, 6 \mathrm{H}, \mathrm{PCH}\left(\mathrm{CH}_{3}\right)_{2}\right), 0.78\left(\mathrm{dvt}, J_{\mathrm{H}-\mathrm{H}}=6.0, N=11.5,18 \mathrm{H}\right.$, $\left.\mathrm{PCH}\left(\mathrm{CH}_{3}\right)_{2}\right), 0.73\left(\mathrm{dvt}, J_{\mathrm{H}-\mathrm{H}}=6.3, N=12.0,18 \mathrm{H}, \mathrm{PCH}\left(\mathrm{CH}_{3}\right)_{2}\right),-9.97$ $\left(\mathrm{t},{ }^{2} J_{\mathrm{H}-\mathrm{P}}=32.3,1 \mathrm{H}, \mathrm{Os}-\mathrm{H}\right) .{ }^{13} \mathrm{C}\left\{{ }^{1} \mathrm{H}\right\}$ NMR $\left(100.61 \mathrm{MHz}, \mathrm{THF}-d_{8}, 253\right.$ $\mathrm{K}): \delta 170.6\left(\mathrm{t},{ }^{2} J_{\mathrm{C}-\mathrm{P}}=8.5\right.$, Os-C), $169.8(\mathrm{~s}, \mathrm{C}$ py), $156.7(\mathrm{~s}, \mathrm{C} \mathrm{pz})$, 155.2 (s, C py), 148.5 (s, C Ph), 144.7 (s, CH Ph), 129.5 (s, CH pz), 129.1 (s, CH Ph), 128.4 (s, CH py), 125.0, 116.3 (both s, CH Ph), 112.8, 111.3 (both s, CH py), 105.7 (s, $\mathrm{CH}$ pz), $41.6\left(\mathrm{~s}, \mathrm{NCH}_{3}\right), 29.9$ (vt, $N=22.8, \mathrm{PCH}\left(\mathrm{CH}_{3}\right)_{2}$ ), 20.2, 19.9 (both s, $\left.\mathrm{PCH}\left(\mathrm{CH}_{3}\right)_{2}\right) .{ }^{31} \mathrm{P}\left\{{ }^{1} \mathrm{H}\right\}$ NMR (161.98 MHz, THF- $\left.d_{8}, 253 \mathrm{~K}\right): \delta 9.0$ (s).

Transformation of OsH $\left\{\kappa^{3}-N, N, C\right.$ - $\left.\left(M e p z-p y-C_{6} H_{4}\right)\right\}\left(P^{i} P_{3}\right)_{2}(4)$ into $\mathrm{OsH}_{2}\left\{\kappa^{3}-C, N, C^{\prime}-\left(\mathrm{Mepz}-\mathrm{py}^{3}-\mathrm{C}_{6} \mathbf{H}_{4}\right)\right\}\left(\mathrm{P}^{\mathrm{i}} \mathrm{Pr}_{3}\right)_{2}$ (5). A solution of 4 $(250 \mathrm{mg}, 0.335 \mathrm{mmol})$ in toluene $(10 \mathrm{~mL})$ was stirred at room temperature for $6 \mathrm{~h}$, changing the color of the solution from dark red to bright orange. After this time the solvent was evaporated to dryness. After cooling at $-78{ }^{\circ} \mathrm{C}$, addition of pentane $(3 \mathrm{~mL})$ caused precipitation of a bright orange solid, that was washed with further portions of pentane $(2 \times 3 \mathrm{~mL})$ and dried in vacuo. Yield: $223 \mathrm{mg}(89 \%)$. Anal. calcd. for $\mathrm{C}_{33} \mathrm{H}_{55} \mathrm{~N}_{3} \mathrm{OsP}_{2}$ : C, 53.15; H, 7.43; N, 5.63. Found: C, 52.82;
$\mathrm{H}, 7.54 ; \mathrm{N}, 5.46$. HRMS (electrospray, $\mathrm{m} / \mathrm{z}$ ) calcd for $\mathrm{C}_{33} \mathrm{H}_{55} \mathrm{~N}_{3} \mathrm{OsP}_{2}$ $[\mathrm{M}]^{+}:$747.3482; found: 747.3468. IR $\left(\mathrm{cm}^{-1}\right): \mathrm{v}(\mathrm{Os}-\mathrm{H}) 2180(\mathrm{w}) .{ }^{1} \mathrm{H}$ NMR $\left(400 \mathrm{MHz}, \mathrm{C}_{6} \mathrm{D}_{6}, 298 \mathrm{~K}\right): \delta 8.50(\mathrm{~m}, 1 \mathrm{H}, \mathrm{Ph}), 7.92\left(\mathrm{~d}, J_{\mathrm{H}-\mathrm{H}}=\right.$ 7.7, $1 \mathrm{H}$, py), $7.84(\mathrm{~m}, 1 \mathrm{H}, \mathrm{Ph}), 7.37\left(\mathrm{~d}, J_{\mathrm{H}-\mathrm{H}}=7.7,1 \mathrm{H}, \mathrm{py}\right), 7.21(\mathrm{~m}$, $2 \mathrm{H}, \mathrm{Ph}), 7.15\left(\mathrm{t}, J_{\mathrm{H}-\mathrm{H}}=7.7,1 \mathrm{H}, \mathrm{py}\right), 7.08(\mathrm{~s}, 1 \mathrm{H}, \mathrm{pz}), 3.65(\mathrm{~s}, 3 \mathrm{H}$, $\left.\mathrm{CH}_{3}\right), 2.17\left(\mathrm{~m}, 6 \mathrm{H}, \mathrm{PCH}\left(\mathrm{CH}_{3}\right)_{2}\right), 1.00\left(\mathrm{dvt}, J_{\mathrm{H}-\mathrm{H}}=5.6, N=12.4,18 \mathrm{H}\right.$, $\left.\mathrm{PCH}\left(\mathrm{CH}_{3}\right)_{2}\right), 0.95\left(\mathrm{dvt}, J_{\mathrm{H}-\mathrm{H}}=6.0, N=12.4,18 \mathrm{H}, \mathrm{PCH}\left(\mathrm{CH}_{3}\right)_{2}\right),-8.48$ $\left(\mathrm{dt},{ }^{2} J_{\mathrm{H}-\mathrm{H}}=13.1,{ }^{2} J_{\mathrm{H}-\mathrm{P}}=14.9,1 \mathrm{H}, \mathrm{Os}-\mathrm{H}\right),-8.69\left(\mathrm{dt},{ }^{2} J_{\mathrm{H}-\mathrm{H}}=13.1,{ }^{2} J_{\mathrm{H}-\mathrm{P}}\right.$ $=14.9,1 \mathrm{H}$, Os-H). ${ }^{13} \mathrm{C}\left\{{ }^{1} \mathrm{H}\right\}$ NMR $\left(100.61 \mathrm{MHz}, \mathrm{C}_{6} \mathrm{D}_{6}, 298 \mathrm{~K}\right): \delta$ $178.8\left(\mathrm{t},{ }^{2} J_{\mathrm{C}-\mathrm{P}}=6.9\right.$, Os-C Ph), 167.5 (s, C Ph), 162.5 (s, C py), 159.5 (s, C pz), 147.3 (s, C py), 146.6 (s, CH Ph), 136.6 (s, CH pz), 135.8 (s, CH py), 133.8 (t, ${ }^{2} J_{\mathrm{C}-\mathrm{P}}=7.9$, Os-C pz), 129.7, 124.8, 119.7 (all s, $\mathrm{CH} \mathrm{Ph}$ ), 111.8, 111.7 (both s, CH py), 38.4 (s, $\mathrm{NCH}_{3}$ ), 26.7 (vt, $N=$ 24.0, $\left.\mathrm{PCH}\left(\mathrm{CH}_{3}\right)_{2}\right), 19.3\left(\mathrm{~s}, \mathrm{PCH}\left(\mathrm{CH}_{3}\right)_{2}\right) .{ }^{31} \mathrm{P}\left\{{ }^{1} \mathrm{H}\right\} \mathrm{NMR}(161.98 \mathrm{MHz}$, $\left.\mathrm{CD}_{2} \mathrm{Cl}_{2}, 298 \mathrm{~K}\right): \delta-0.5$ (s). $T_{1}(\min )\left(400 \mathrm{MHz}, \mathrm{CD}_{2} \mathrm{Cl}_{2}, 213 \mathrm{~K}\right): 107 \pm$ $1 \mathrm{~ms}(-8.48 \mathrm{ppm}), 107 \pm 1 \mathrm{~ms}(-8.69 \mathrm{ppm})$.

NMR Spectroscopic Study of the Transformation of 4 into 5 . The experimental procedure is described for a particular case, but the same method was used in all experiments. In an NMR tube complex 4 $(20 \mathrm{mg})$ was dissolved in benzene- $d_{6}(0.4 \mathrm{~mL})$. The tube was immediately introduced in an NMR probe at the desired temperature and the reaction was monitored by ${ }^{1} \mathrm{H}$ NMR intervals of time. In order to ensure accurate integration of the signals, the spectra were recorded with a $2.5 \mathrm{~s}$ delay.

Reaction of $\mathrm{OsH}_{2}\left\{\kappa^{3}-C, N, C^{\prime}-\left(\mathrm{Mepz}-\mathrm{py}-\mathrm{C}_{6} \mathrm{H}_{4}\right)\right\}\left(\mathrm{P}^{\mathrm{i}} \mathrm{Pr}_{3}\right)_{2}$ (5) with MeOTf: Preparation of $\left[\mathrm{OsH}_{2}\left\{\mathrm{~K}^{3}-C, N, C^{\prime}-\left(\mathrm{Me}_{2} \mathrm{pz}-\mathrm{py}-\right.\right.\right.$ $\left.\left.\mathbf{C}_{6} \mathbf{H}_{4}\right)\right\}\left(\mathbf{P}^{\mathbf{i}} \mathbf{P r}_{3}\right)_{2}$ ]OTf (6). A solution of $\mathbf{5}(250 \mathrm{mg}, 0.335 \mathrm{mmol})$ in diethyl ether $(5 \mathrm{~mL})$ was treated with MeOTf $(42 \mu \mathrm{L}, 0.368 \mathrm{mmol})$, getting a dark red suspension that was stirred at room temperature for $30 \mathrm{~min}$. The red solid was decanted, washed with further portions of diethyl ether $(3 \times 4 \mathrm{~mL})$ and dried in vacuo. Yield: $260 \mathrm{mg}(85 \%)$. Anal. calcd. for $\mathrm{C}_{35} \mathrm{H}_{58} \mathrm{~F}_{3} \mathrm{~N}_{3} \mathrm{O}_{3} \mathrm{OsP}_{2} \mathrm{~S}$ : C, 46.19; H, 6.42; N, 4.62; S, 3.52. Found: $\mathrm{C}, 45.99 ; \mathrm{H}, 6.75$; N, 4.8; S, 3.85. HRMS (electrospray, $m / z$ ) calcd for $\mathrm{C}_{34} \mathrm{H}_{58} \mathrm{~N}_{3} \mathrm{OsP}_{2}[\mathrm{M}]^{+}: 762.3717$; found: 762.3734. IR $\left(\mathrm{cm}^{-1}\right)$ : v(Os-H) $2164(\mathrm{w}), v\left(\mathrm{CF}_{3}\right) 1254$ (vs), v(SO) 1223, 1151, 1029 (vs). ${ }^{1} \mathrm{H}$ NMR $\left(400 \mathrm{MHz}, \mathrm{CD}_{2} \mathrm{Cl}_{2}, 298 \mathrm{~K}\right): \delta 7.99\left(\mathrm{~d}, J_{\mathrm{H}-\mathrm{H}}=7.3,1 \mathrm{H}\right.$, $\mathrm{Ph}), 7.77\left(\mathrm{dd}, J_{\mathrm{H}-\mathrm{H}}=7.3, J_{\mathrm{H}-\mathrm{H}}=1.7,1 \mathrm{H}, \mathrm{py}\right), 7.73\left(\mathrm{dd}, J_{\mathrm{H}-\mathrm{H}}=7.3, J_{\mathrm{H}-\mathrm{H}}\right.$ $=1.3,1 \mathrm{H}, \mathrm{Ph}), 7.65-7.59(\mathrm{~m}, 2 \mathrm{H}, \mathrm{py}), 7.55(\mathrm{~s}, 1 \mathrm{H}, \mathrm{pz}), 6.98\left(\mathrm{t}, J_{\mathrm{H}-\mathrm{H}}=\right.$ $7.3,1 \mathrm{H}, \mathrm{Ph}), 6.91\left(\mathrm{td}, J_{\mathrm{H}-\mathrm{H}}=7.3, J_{\mathrm{H}-\mathrm{H}}=1.3,1 \mathrm{H}, \mathrm{Ph}\right), 4.45,4.19$ (both $\mathrm{s}, 3 \mathrm{H}$ each, $\left.\mathrm{CH}_{3}\right), 1.91\left(\mathrm{~m}, 6 \mathrm{H}, \mathrm{PCH}\left(\mathrm{CH}_{3}\right)_{2}\right), 0.81\left(\mathrm{dvt}, J_{\mathrm{H}-\mathrm{H}}=6.8, N=\right.$ $\left.12.8,18 \mathrm{H}, \mathrm{PCH}\left(\mathrm{CH}_{3}\right)_{2}\right), 0.77\left(\mathrm{dvt}, J_{\mathrm{H}-\mathrm{H}}=7.2, N=12.8,18 \mathrm{H}\right.$, $\left.\mathrm{PCH}\left(\mathrm{CH}_{3}\right)_{2}\right),-7.92\left(\mathrm{dt},{ }^{2} J_{\mathrm{H}-\mathrm{H}}=17.6,{ }^{2} J_{\mathrm{H}-\mathrm{P}}=15.1,1 \mathrm{H}, \mathrm{Os}-\mathrm{H}\right),-8.41(\mathrm{dt}$, $\left.{ }^{2} J_{\mathrm{H}-\mathrm{H}}=17.6,{ }^{2} J_{\mathrm{H}-\mathrm{P}}=15.1,1 \mathrm{H}, \mathrm{Os}-\mathrm{H}\right) .{ }^{13} \mathrm{C}\left\{{ }^{1} \mathrm{H}\right\}$ NMR $(100.61 \mathrm{MHz}$, $\left.\mathrm{CD}_{2} \mathrm{Cl}_{2}, 298 \mathrm{~K}\right): \delta 177.2\left(\mathrm{t},{ }^{2} J_{\mathrm{C}-\mathrm{P}}=7.1\right.$, Os-C Ph), $169.3(\mathrm{~s}, \mathrm{C} \mathrm{Ph})$, 153.8 (s, C py), 151.3 (s, C pz), 146.3 (s, CH Ph), 145.5 (s, C py), 142.3 (s, CH pz), 141.0 (t, ${ }^{2} J_{\mathrm{C}-\mathrm{P}}=6.9$, Os-C pz), 136.5 (s, CH py), 131.1, 126.0 (both s, $\mathrm{CH} \mathrm{Ph}$ ), $121.5\left(\mathrm{q},{ }^{1} J_{\mathrm{C}-\mathrm{F}}=313.9, \mathrm{CF}_{3} \mathrm{SO}_{3}\right), 120.4$ (s, $\mathrm{CH} \mathrm{Ph}$ ), 115.7, 114.7 (both s, $\mathrm{CH}$ py), 37.5, 35.7 (both s, $\mathrm{NCH}_{3}$ ), 27.2 (vt, $\left.N=25.2, \operatorname{PCH}\left(\mathrm{CH}_{3}\right)_{2}\right), 19.3,19.2$ (both s, $\left.\mathrm{PCH}\left(\mathrm{CH}_{3}\right)_{2}\right)$. ${ }^{31} \mathrm{P}\left\{{ }^{1} \mathrm{H}\right\}$ NMR $\left(161.98 \mathrm{MHz}, \mathrm{CD}_{2} \mathrm{Cl}_{2}, 298 \mathrm{~K}\right): \delta-0.3(\mathrm{~s}) .{ }^{19} \mathrm{~F}\left\{{ }^{1} \mathrm{H}\right\}$ NMR (282.33 MHz, $\left.\mathrm{CD}_{2} \mathrm{Cl}_{2}, 298 \mathrm{~K}\right): \delta$-78.9. $T_{1}(\min )(400 \mathrm{MHz}$, $\left.\mathrm{CD}_{2} \mathrm{Cl}_{2}, 233 \mathrm{~K}\right): 105 \pm 2 \mathrm{~ms}(-7.92 \mathrm{ppm}), 105 \pm 2 \mathrm{~ms}(-8.41 \mathrm{ppm})$.

Reaction of $\mathrm{OsH}_{6}\left(\mathrm{P}^{\mathrm{i}} \mathrm{Pr}_{3}\right)_{2}$ (1) with 2-(1H-pyrazol-3-yl)pyridine: Preparation of $\mathrm{OsH}_{3}\left\{\mathrm{~K}^{2}-N, N-(\mathrm{pz}-\mathrm{py})\right\}\left(\mathrm{P}^{\mathrm{i}} \mathrm{Pr}_{3}\right)_{2}$ (7). A solution of 1 $(250 \mathrm{mg}, 0.484 \mathrm{mmol})$ in toluene $(7 \mathrm{~mL})$ was treated with $2-(1 H-$ pyrazol-3-yl)pyridine $(70.2 \mathrm{mg}, 0.484 \mathrm{mmol})$. The resulting mixture was refluxed for $1.5 \mathrm{~h}$, getting a dark yellow solution. After cooling at room temperature the solvent was removed in vacuo, affording a dark yellow residue. Addition of pentane $(4 \mathrm{~mL})$ afforded a yellow solid, which was washed with further portions of pentane $(2 \times 4 \mathrm{~mL})$ and dried in vacuo. Yield: $270 \mathrm{mg}(85 \%)$. Anal. calcd. for $\mathrm{C}_{26} \mathrm{H}_{51} \mathrm{~N}_{3} \mathrm{OsP}_{2}$ : C, 47.47; H, 7.81; N, 6.39; found: C, 47.44; H, 7.76; N, 6.54. HRMS (electrospray, $m / z$ ) calcd for $\mathrm{C}_{26} \mathrm{H}_{52} \mathrm{~N}_{3} \mathrm{OsP}_{2}[\mathrm{M}+\mathrm{H}]^{+}$: 660.3247 ; found: 660.3252. IR $\left(\mathrm{cm}^{-1}\right): v(\mathrm{Os}-\mathrm{H}) 2089$ (w). ${ }^{1} \mathrm{H}$ NMR $\left(300 \mathrm{MHz}, \mathrm{C}_{6} \mathrm{D}_{6}\right.$, $298 \mathrm{~K}): \delta 9.23\left(\mathrm{~d}, J_{\mathrm{H}-\mathrm{H}}=5.8,1 \mathrm{H}, \mathrm{py}\right), 8.11\left(\mathrm{~d}, J_{\mathrm{H}-\mathrm{H}}=2.0,1 \mathrm{H}, \mathrm{pz}\right)$, $7.19\left(\mathrm{~m}, 1 \mathrm{H}\right.$, py), $6.84\left(\mathrm{t}, J_{\mathrm{H}-\mathrm{H}}=7.7,1 \mathrm{H}, \mathrm{py}\right), 6.78\left(\mathrm{~d}, J_{\mathrm{H}-\mathrm{H}}=2.0,1 \mathrm{H}\right.$, pz), $6.18\left(\mathrm{ddd}, J_{\mathrm{H}-\mathrm{H}}=7.3, J_{\mathrm{H}-\mathrm{H}}=5.8, J_{\mathrm{H}-\mathrm{H}}=1.5,1 \mathrm{H}, \mathrm{py}\right), 1.78(\mathrm{~m}, 6 \mathrm{H}$, $\left.\mathrm{PCH}\left(\mathrm{CH}_{3}\right)_{2}\right), 1.01\left(\mathrm{dvt}, J_{\mathrm{H}-\mathrm{H}}=7.0, N=12.5,18 \mathrm{H}, \mathrm{PCH}\left(\mathrm{CH}_{3}\right)_{2}\right), 0.97$ $\left(\mathrm{dvt}, J_{\mathrm{H}-\mathrm{H}}=7.0, N=12.5,18 \mathrm{H}, \mathrm{PCH}\left(\mathrm{CH}_{3}\right)_{2}\right),-10.53\left(\mathrm{t},{ }^{2} J_{\mathrm{H}-\mathrm{P}}=12.5\right.$, $3 \mathrm{H}$, Os-H). ${ }^{1} \mathrm{H}\left\{{ }^{31} \mathrm{P}\right\}$ NMR $\left(400 \mathrm{MHz}\right.$, toluene- $d_{8}, 203 \mathrm{~K}$, high field region): $\delta-10.33\left(\mathrm{t},{ }^{2} J_{\mathrm{H}-\mathrm{H}}=18.2,1 \mathrm{H}, \mathrm{Os}-\mathrm{H}\right),-10.56\left(\mathrm{~d},{ }^{2} J_{\mathrm{H}-\mathrm{H}}=18.2\right.$, 
2H, Os-H). ${ }^{13} \mathrm{C}\left\{{ }^{1} \mathrm{H}\right\}$ NMR $\left(75.42 \mathrm{MHz}, \mathrm{C}_{6} \mathrm{D}_{6}, 298 \mathrm{~K}\right): \delta 155.9(\mathrm{~s}, \mathrm{CH}$ py), 155.8 (s, C py), 148.5 (s, C pz), 141.1 (s, CH pz), 134.1 (s, CH py), 119.3 (s, CH py), 118.7 (s, CH py), 103.1 (s, CH pz), 27.0 (vt, $N$ $\left.=23.7, \mathrm{PCH}\left(\mathrm{CH}_{3}\right)_{2}\right), 19.9,19.8$ (both $\left.\mathrm{s}, \mathrm{PCH}\left(\mathrm{CH}_{3}\right)_{2}\right) .{ }^{31} \mathrm{P}\left\{{ }^{1} \mathrm{H}\right\} \mathrm{NMR}$ $\left(121.4 \mathrm{MHz}, \mathrm{C}_{6} \mathrm{D}_{6}, 298 \mathrm{~K}\right): \delta 15.7(\mathrm{~s}) . T_{1}(\mathrm{~min})\left(400 \mathrm{MHz}\right.$, toluene- $d_{8}$, $218 \mathrm{~K}): 106 \pm 5 \mathrm{~ms}(-10.33 \mathrm{ppm}), 106 \pm 5 \mathrm{~ms}(-10.56 \mathrm{ppm})$.

Reaction of $\mathrm{OsH}_{3}\left\{\mathrm{~K}^{2}-N, N-(\mathrm{pz}-\mathrm{py})\right\}\left(\mathrm{P}^{\mathrm{i}} \mathrm{Pr}_{3}\right)_{2}$ (7) with MeOTf: Preparation of $\left[\mathrm{OsH}_{3}\left\{\boldsymbol{K}^{2}-\mathbf{N}, \boldsymbol{N}\right.\right.$-(Mepz-py) $\left.\}\left(\mathrm{P}^{\mathrm{i}} \mathrm{Pr}_{3}\right)_{2}\right] \mathrm{OTf} \quad(8)$. A solution of $7(250 \mathrm{mg}, 0.380 \mathrm{mmol})$ in diethyl ether $(8 \mathrm{~mL})$ was treated with MeOTf (48 $\mu \mathrm{L}, 0.418 \mathrm{mmol})$, getting a yellow suspension. The suspension was decanted, and the solid washed with further portions of diethyl ether ( $3 \times 4 \mathrm{~mL})$ and dried in vacuo. Yield: $287 \mathrm{mg}$ (92\%). Anal. calcd. for $\mathrm{C}_{28} \mathrm{H}_{54} \mathrm{~F}_{3} \mathrm{~N}_{3} \mathrm{O}_{3} \mathrm{OsP}_{2} \mathrm{~S}$ : C, 40.91; H, 6.62; N, 5.11; S, 3.90; found: $\mathrm{C}, 40.53 ; \mathrm{H}, 6.62 ; \mathrm{N}, 5.30 ; \mathrm{S}, 3.61$. HRMS (electrospray, $\mathrm{m} / \mathrm{z}$ ) calcd for $\mathrm{C}_{27} \mathrm{H}_{54} \mathrm{~N}_{3} \mathrm{OsP}_{2}[\mathrm{M}]^{+}$: 674.3403; found: 674.3412. IR $\left(\mathrm{cm}^{-1}\right): v(\mathrm{Os}-\mathrm{H}) 2120(\mathrm{w}), v\left(\mathrm{CF}_{3}\right) 1278(\mathrm{vs}), v(\mathrm{SO})$ 1246, 1151, 1028 (vs). ${ }^{1} \mathrm{H}$ NMR (400 MHz, $\mathrm{CD}_{2} \mathrm{Cl}_{2}, 298 \mathrm{~K}$ ): $\delta 9.27$ $\left(\mathrm{d}, J_{\mathrm{H}-\mathrm{H}}=5.5,1 \mathrm{H}, \mathrm{py}\right), 8.01\left(\mathrm{~d}, J_{\mathrm{H}-\mathrm{H}}=7.7,1 \mathrm{H}, \mathrm{py}\right), 7.97\left(\mathrm{~d}, J_{\mathrm{H}-\mathrm{H}}=2.8\right.$, $1 \mathrm{H}, \mathrm{pz}), 7.86\left(\mathrm{t}, J_{\mathrm{H}-\mathrm{H}}=7.7,1 \mathrm{H}, \mathrm{py}\right), 7.25\left(\mathrm{dd}, J_{\mathrm{H}-\mathrm{H}}=7.7, J_{\mathrm{H}-\mathrm{H}}=5.5\right.$, $1 \mathrm{H}, \mathrm{py}), 7.11\left(\mathrm{~d}, J_{\mathrm{H}-\mathrm{H}}=2.8,1 \mathrm{H}, \mathrm{pz}\right), 4.24\left(\mathrm{~s}, 3 \mathrm{H}, \mathrm{CH}_{3}\right), 1.86(\mathrm{~m}, 6 \mathrm{H}$, $\left.\mathrm{PCH}\left(\mathrm{CH}_{3}\right)_{2}\right), 0.92\left(\mathrm{dvt}, J_{\mathrm{H}-\mathrm{H}}=7.2, N=13.2,18 \mathrm{H}, \mathrm{PCH}\left(\mathrm{CH}_{3}\right)_{2}\right), 0.87$ $\left(\mathrm{dvt}, J_{\mathrm{H}-\mathrm{H}}=7.2, N=12.8,18 \mathrm{H}, \mathrm{PCH}\left(\mathrm{CH}_{3}\right)_{2}\right),-11.02\left(\mathrm{t},{ }^{2} J_{\mathrm{H}-\mathrm{P}}=12.5\right.$, $3 \mathrm{H}$, Os-H). ${ }^{1} \mathrm{H}\left\{{ }^{31} \mathrm{P}\right\}$ NMR $\left(400 \mathrm{MHz}, \mathrm{CD}_{2} \mathrm{Cl}_{2}, 193 \mathrm{~K}\right.$, high field region): $\delta-11.06$ (br, 3H, Os-H). ${ }^{13} \mathrm{C}\left\{{ }^{1} \mathrm{H}\right\}$ NMR (100.61 MHz, $\mathrm{CD}_{2} \mathrm{Cl}_{2}, 298 \mathrm{~K}$ ): $\delta 155.8$ (s, CH py), 151.5 (s, C py), 151.1 (s, C pz), 137.0 (s, CH py), 135.9 (s, CH pz), 125.5, 122.9 (both s, CH py), $121.1\left(\mathrm{q},{ }^{1} J_{\mathrm{C}-\mathrm{F}}=320.1, \mathrm{CF}_{3} \mathrm{SO}_{3}\right), 106.7(\mathrm{~s}, \mathrm{CH} \mathrm{pz}), 42.2\left(\mathrm{~s}, \mathrm{NCH}_{3}\right)$, 27.4 (vt, $\left.N=25.0, \mathrm{PCH}\left(\mathrm{CH}_{3}\right)_{2}\right), 19.8,19.7$ (both s, $\mathrm{PCH}\left(\mathrm{CH}_{3}\right)_{2}$ ). ${ }^{31} \mathrm{P}\left\{{ }^{1} \mathrm{H}\right\}$ NMR $\left(121.4 \mathrm{MHz}, \mathrm{CD}_{2} \mathrm{Cl}_{2}, 298 \mathrm{~K}\right): \delta 17.5(\mathrm{~s}) .{ }^{19} \mathrm{~F}\left\{{ }^{1} \mathrm{H}\right\} \mathrm{NMR}$ (282 MHz, $\left.\mathrm{CD}_{2} \mathrm{Cl}_{2}, 298 \mathrm{~K}\right): \delta$-79.1. $T_{1}(\mathrm{~min})\left(400 \mathrm{MHz}, \mathrm{CD}_{2} \mathrm{Cl}_{2}, 218\right.$ $\mathrm{K}): 108 \pm 5 \mathrm{~ms}(-11.03 \mathrm{ppm})$.

Reaction of $\left[\mathrm{OsH}_{3}\left\{\mathrm{~K}^{2}-N, N-(\mathrm{Mepz}-\mathrm{py})\right\}\left(\mathrm{P}^{\mathrm{i}} \mathrm{Pr}_{3}\right)_{2}\right] \mathrm{OTf}$ (8) with $\mathrm{K}^{\mathrm{t} B u O:}$ Preparation of $\mathrm{OsH}_{2}\left\{\kappa^{2}-N, N-(\mathrm{Mepz}-\mathrm{py})\right\}\left(\mathrm{P}^{\mathrm{i}} \mathrm{Pr}_{3}\right)_{2}$ (9). A solution of $8(220 \mathrm{mg}, 0.268 \mathrm{mmol})$ in tetrahydrofuran $(8 \mathrm{~mL})$ was treated with $\mathrm{K}^{\mathrm{t}} \mathrm{BuO}(36 \mathrm{mg}, 0.321 \mathrm{mmol})$, getting a dark red solution. After stirring for $5 \mathrm{~min}$ at this temperature, the solvent was evaporated to dryness affording a dark red residue. Toluene $(5 \mathrm{~mL})$ was added and the resulting suspension was filtered to afford a dark red solution that was dried in vacuo to afford a dark red residue. After cooling at $-78^{\circ} \mathrm{C}$, addition of pentane $(3 \mathrm{~mL})$ afforded a dark red solid that was dried in vacuo. Yield: $124 \mathrm{mg}(69 \%)$. Anal. calcd. for $\mathrm{C}_{27} \mathrm{H}_{53} \mathrm{~N}_{3} \mathrm{OsP}_{2}$ : C, 48.26; H, 7.95; N, 6.25; found: C, 48.31; H, 8.15; $\mathrm{N}, 6.44$. HRMS (electrospray, $\mathrm{m} / \mathrm{z}$ ) calcd for $\mathrm{C}_{27} \mathrm{H}_{54} \mathrm{~N}_{3} \mathrm{OsP}_{2}[\mathrm{M}+\mathrm{H}]^{+}$: 674.3403; found: 674.3406. IR ( $\left.\mathrm{cm}^{-1}\right): v(\mathrm{Os}-\mathrm{H}) 2160$ (w). ${ }^{1} \mathrm{H}$ NMR $\left(400 \mathrm{MHz}, \mathrm{C}_{6} \mathrm{D}_{6}, 298 \mathrm{~K}\right): \delta 9.76\left(\mathrm{~d}, J_{\mathrm{H}-\mathrm{H}}=6.0,1 \mathrm{H}, \mathrm{py}\right), 7.27\left(\mathrm{~d}, J_{\mathrm{H}-\mathrm{H}}\right.$ $=6.0,1 \mathrm{H}, \mathrm{py}), 6.92\left(\mathrm{~d}, J_{\mathrm{H}-\mathrm{H}}=2.8,1 \mathrm{H}, \mathrm{pz}\right), 6.91(\mathrm{~m}, 1 \mathrm{H}, \mathrm{py}), 6.60(\mathrm{~d}$, $\left.J_{\mathrm{H}-\mathrm{H}}=2.8,1 \mathrm{H}, \mathrm{pz}\right), 6.28\left(\mathrm{t}, J_{\mathrm{H}-\mathrm{H}}=6.0,1 \mathrm{H}, \mathrm{py}\right), 3.96\left(\mathrm{~s}, 3 \mathrm{H}, \mathrm{CH}_{3}\right)$, $2.09\left(\mathrm{~m}, 6 \mathrm{H}, \mathrm{PCH}\left(\mathrm{CH}_{3}\right)_{2}\right), 1.02\left(\mathrm{dvt}, J_{\mathrm{H}-\mathrm{H}}=6.9, N=12.5,18 \mathrm{H}\right.$, $\left.\mathrm{PCH}\left(\mathrm{CH}_{3}\right)_{2}\right), 0.96\left(\mathrm{dvt}, J_{\mathrm{H}-\mathrm{H}}=6.3, N=12.1,18 \mathrm{H}, \mathrm{PCH}\left(\mathrm{CH}_{3}\right)_{2}\right)$, $15.57\left(\mathrm{dt},{ }^{2} J_{\mathrm{H}-\mathrm{H}}=2.8,{ }^{2} J_{\mathrm{H}-\mathrm{P}}=27.0,1 \mathrm{H}, \mathrm{Os}-\mathrm{H}\right),-15.99\left(\mathrm{dt},{ }^{2} J_{\mathrm{H}-\mathrm{H}}=2.8\right.$, $\left.{ }^{2} J_{\mathrm{H}-\mathrm{P}}=27.0,1 \mathrm{H}, \mathrm{Os}-\mathrm{H}\right) .{ }^{1} \mathrm{H}\left\{{ }^{31} \mathrm{P}\right\}$ NMR $\left(400 \mathrm{MHz}, \mathrm{C}_{6} \mathrm{D}_{6}, 193 \mathrm{~K}\right.$, high field region): $\delta-15.43$ (br d, $1 \mathrm{H}, \mathrm{Os}-\mathrm{H}),-15.82(\mathrm{br} \mathrm{d}, 1 \mathrm{H}, \mathrm{Os}-\mathrm{H})$. ${ }^{13} \mathrm{C}\left\{{ }^{1} \mathrm{H}\right\}$ NMR (100.61 MHz, $\left.\mathrm{C}_{6} \mathrm{D}_{6}, 298 \mathrm{~K}\right): \delta 158.2(\mathrm{~s}, \mathrm{CH}$ py), 154.5 (s, C py), 151.6 (s, C pz), 126.3 (s, CH py), 124.0 (s, CH pz), 121.5, 121.0 (both s, $\mathrm{CH}$ py), 103.6 (s, $\mathrm{CH}$ pz), $40.5\left(\mathrm{~s}, \mathrm{NCH}_{3}\right), 30.5$ (vt, $N=$ 22.0, $\left.\mathrm{PCH}\left(\mathrm{CH}_{3}\right)_{2}\right), 20.3,20.1$ (both s, $\left.\mathrm{PCH}\left(\mathrm{CH}_{3}\right)_{2}\right) .{ }^{31} \mathrm{P}\left\{{ }^{1} \mathrm{H}\right\}$ NMR $\left(121.4 \mathrm{MHz}, \mathrm{C}_{6} \mathrm{D}_{6}, 298 \mathrm{~K}\right): \delta 29.8(\mathrm{~s}) . T_{1}(\mathrm{~min})\left(400 \mathrm{MHz}\right.$, toluene- $d_{8}$, $223 \mathrm{~K}): 350 \pm 2 \mathrm{~ms}(-15.55 \mathrm{ppm}), 353 \pm 2 \mathrm{~ms}(-16.00 \mathrm{ppm})$.

Structural Analysis of Complexes 2, 5, and 7. X-ray data were collected for the complexes on a Bruker Smart APEX CCD diffractometer equipped with a normal focus, $2.4 \mathrm{~kW}$ sealed tube source (Mo radiation, $\lambda=0.71073 \AA$ ) operating at $50 \mathrm{kV}$ and $40 \mathrm{~mA}$ (7) or $30 \mathrm{~mA}$ ( 2 and 5). Data were collected over the complete sphere. Each frame exposure time was $10 \mathrm{~s} \mathrm{(2}$ and 5) or $20 \mathrm{~s}$ (7) covering $0.3^{\circ}$ in $\omega$ in. Data were corrected for absorption by using a multiscan method applied with the SADABS program. ${ }^{35}$ The structures were solved by Patterson or direct methods and refined by full-matrix least squares on $\mathrm{F}^{2}$ with SHELXL2016, ${ }^{36}$ including isotropic and subsequently anisotropic displacement parameters. The hydrogen atoms were observed in the least Fourier Maps or calculated, and refined freely or using a restricted riding model. The hydrogen bonded to metal atoms were observed in the last cycles of refinement but refined too close to metals, so a restricted refinement model was used for all of them $(\mathrm{d}(\mathrm{Os}-\mathrm{H})=1.59(1) \AA)$.

Crystal data for 2: $\mathrm{C}_{32} \mathrm{H}_{53} \mathrm{~N}_{3} \mathrm{OsP}_{2}, 2\left(\mathrm{CH}_{4} \mathrm{O}\right), \mathrm{M}_{\mathrm{W}} 795.99$, orange, irregular block $(0.212 \times 0.141 \times 0.128 \mathrm{~mm})$, monoclinic, space group $\mathrm{P} 21 / \mathrm{c}, a: 16.9732(8) \AA, b: 13.4054(6) \AA, c: 16.3797(8) \AA ⿻$ 98.2780(10) $, V=3688.1(3) \AA^{3}, Z=4, Z^{\prime}=1, \mathrm{D}_{\text {calc }}: 1.434 \mathrm{~g} \mathrm{~cm}^{-3}$, $\mathrm{F}(000): 1632, \mathrm{~T}=100(2) \mathrm{K}, \mu 3.576 \mathrm{~mm}^{-1} .42643$ measured reflections $\left(2 \theta: 3-58^{\circ}\right.$, $\omega$ scans $\left.0.3^{\circ}\right), 8943$ unique $\left(\mathrm{R}_{\text {int }}=0.0408\right) ; \min . / \max$. transm. factors $0.718 / 0.862$. Final agreement factors were $\mathrm{R}^{1}=0.0271$ (7625 observed reflections, I $>2 \sigma(\mathrm{I})$ ) and $\mathrm{wR}^{2}=0.0539$; data/restraints/parameters 8943/4/402; GoF $=1.092$. Largest peak and hole 1.916 (close to the osmium atom) and $-0.671 \mathrm{e} / \AA^{3}$.

Crystal data for 5: $\mathrm{C}_{33} \mathrm{H}_{55} \mathrm{~N}_{3} \mathrm{OsP}_{2}, \mathrm{CH}_{4} \mathrm{O}, \mathrm{M}_{\mathrm{W}} 777.98$, black, irregular block $(0.172 \times 0.138 \times 0.088 \mathrm{~mm})$, monoclinic, space group $\mathrm{P}_{1} / \mathrm{n}$, $a: \quad 11.0767(5) \quad \AA, \quad b: 14.5769(7) \quad \AA, \quad c: 22.1570(11) \AA, \quad \beta:$ 103.8890(10) ${ }^{\circ}, V=3473.0(3) \AA^{3}, Z=4, Z^{\prime}=1, \mathrm{D}_{\text {calc }}: 1.488 \mathrm{~g} \mathrm{~cm}^{-3}$, $\mathrm{F}(000): 1592, \mathrm{~T}=100(2) \mathrm{K}, \mu 3.794 \mathrm{~mm}^{-1} .60272$ measured reflections $\left(2 \theta: 3-57^{\circ}\right.$, $\omega$ scans $\left.0.3^{\circ}\right), 8516$ unique $\left(\mathrm{R}_{\text {int }}=0.0454\right)$; min. $/$ max. transm. factors $0.738 / 0.862$. Final agreement factors were $\mathrm{R}^{1}=0.0276$ (7312 observed reflections, I $>2 \sigma(\mathrm{I})$ ) and $\mathrm{wR}^{2}=0.0594$; data/restraints/parameters $8516 / 2 / 394 ; \mathrm{GoF}=1.055$. Largest peak and hole 1.288 (close to the osmium atom) and $-1.383 \mathrm{e} / \AA^{3}$.

Crystal data for 7: $\mathrm{C}_{26} \mathrm{H}_{51} \mathrm{~N}_{3} \mathrm{OsP}_{2}, \mathrm{M}_{\mathrm{W}}$ 657.83, yellow, irregular block $(0.300 \times 0.057 \times 0.048 \mathrm{~mm})$, monoclinic, space group $\mathrm{P} 2{ }_{1} / \mathrm{c}, a$ : 9.4616(6) $\AA, b: 32.698(2) \AA, c: 27.7168(17) \AA, \beta: 90.0450(10)^{\circ}, V=$ 8574.9(9) $\AA^{3}, Z=12, Z^{\prime}=3$, D calc: $1.529 \mathrm{~g} \mathrm{~cm}^{-3}, \mathrm{~F}(000): 4008, \mathrm{~T}=$ $100(2) \mathrm{K}, \mu 4.591 \mathrm{~mm}^{-1} .86590$ measured reflections $\left(2 \theta: 3-57^{\circ}, \omega\right.$ scans $\left.0.3^{\circ}\right), 20357$ unique $\left(\mathrm{R}_{\text {int }}=0.0846\right)$; min. $/ \max$. transm. factors $0.681 / 0.862$. Final agreement factors were $R^{1}=0.0520(14812 \mathrm{ob}-$ served reflections, $\mathrm{I}>2 \sigma(\mathrm{I}))$ and $\mathrm{wR}^{2}=0.0853$; data/restraints/parameters 20357/15/930; $\mathrm{GoF}=1.082$. Largest peak and hole 1.731 (close to the osmium atoms) and $-1.478 \mathrm{e} / \AA^{3}$.

Computational Details. All calculations were performed at the DFT level using the B3LYP functiona ${ }^{37}$ supplemented with the Grimme's dispersion correction $\mathrm{D}^{38}$ as implemented in Gaussian $09 .{ }^{39}$ The Os atoms were described by means of an effective core potential SDD for the inner electron ${ }^{40}$ and its associated double- $\zeta$ basis set for the outer ones, complemented with a set of f-polarization functions for osmium. ${ }^{41}$ The $6-31 \mathrm{G}^{* *}$ basis set was used for the $\mathrm{H}, \mathrm{C}$, $\mathrm{N}$ and $\mathrm{P}$ atoms. ${ }^{42}$ All minima were verified to have no negative frequencies. The geometries were fully optimized in vacuo and in THF $(\varepsilon=7.4257)$ solvent using the continuum SMD model. ${ }^{43}$ We performed TD-DFT calculations at the same level of theory in THF calculating the lowest 50 singlet-singlet excitations at the ground state $S_{0}$. It has to be noticed that the singlet-triplet excitations are set to zero due to the neglect of spin-orbit coupling in the TDDFT calculations as implemented in G09. The phosphorescence emission was calculated as the difference in energy between the optimized triplet in vacuum and the singlet with the same geometry ( $\triangle \mathrm{SCF}$ approximation). The UV/vis absorption spectra were obtained by using the GaussSum 3 software. ${ }^{44}$

\section{ASSOCIATED CONTENT}

\section{Supporting Information}

The Supporting Information is available free of charge on the ACS Publications website.

${ }^{1} \mathrm{H}$ NMR, ${ }^{13} \mathrm{C}\left\{{ }^{1} \mathrm{H}\right\}$ APT and ${ }^{31} \mathrm{P}\left\{{ }^{1} \mathrm{H}\right\}$ NMR spectra of complexes 2-9, experimental and computed UV/vis spectra, normalized emission and excitation spectra, and orbital composition for complexes $\mathbf{2}, \mathbf{3}, \mathbf{5}, \mathbf{7}$, and $\mathbf{8}(\mathrm{PDF})$.

Crystallographic data for compounds 2, 5, and 7 (CIF).

Cartesian coordinates of the computed complexes (XYZ). 


\section{AUTHOR INFORMATION}

\section{Corresponding Author}

* E-mail: maester@unizar.es

Notes

The authors declare no competing financial interest.

\section{ACKNOWLEDGMENT}

Financial support from the MINECO of Spain (Project CTQ201452799-P), the Diputación General de Aragón (E-35), FEDER, and the European Social Fund is acknowledged.

\section{REFERENCES AND NOTES}

(1) See for example: (a) Lai, S.-W.; Chan, Q. K.-W.; Zhu, N.; Che, C.-M. Inorg. Chem. 2007, 46, 11003-11016. (b) Chen, J.-L.; Chi, Y.; Chen, K.; Cheng, Y.-M.; Chung, M.-W.; Yu, Y.-C.; Lee, G.-H.; Chou, P.-T.; Shu, C.-F. Inorg. Chem. 2010, 49, 823-832. (c) Bhaumik, C.; Saha, D.; Das, S.; Baitalik, S. Inorg. Chem. 2011, 50, 12586-12600. (d) Chung, L.-H.; Chan, S.-C.; Lee, W.-C.; Wong, C.Y. Inorg. Chem. 2012, 51, 8693-8703. (e) Hsu, C.-C.; Lin, C.-C.; Chou, P.-T.; Lai, C.-H.; Hsu, C.-W.; Lin, C.-H.; Chi, Y. J. Am. Chem. Soc. 2012, 134, 7715-7724. (f) Chu, W.-K.; Yiu, S.-M.; Ko, C.-C. Organometallics 2014, 33, 6771-6777. (g) Liao, J.-L.; Chi, Y.; Su, Y.-D.; Huang, H.-X.; Chang, C.-H.; Liu, S.-H.; Lee, G.-H.; Chou, P.T. J. Mater. Chem. C 2014, 2, 6269-6282. (h) Alabau, R. G.; Eguillor, B.; Esler, J.; Esteruelas, M. A.; Oliván, M.; Oñate, E.; Tsai, J.-Y.; Xia, C. Organometallics 2014, 33, 5582-5596. (i) Alabau, R. G.; Esteruelas, M. A.; Oliván, M.; Oñate, E.; Palacios, A. U.; Tsai, J.-Y.; Xia, C. Organometallics 2016, 35, 3981-3995.

(2) (a) Chou, P.-T.; Chi, Y. Eur. J. Inorg. Chem. 2006, 2006, 33193332. (b) Evans, R. C.; Douglas, P.; Winscom, C. J. Coord. Chem. Rev. 2006, 250, 2093-2126. (c) Chi, Y.; Chou, P.-T. Chem. Soc. Rev. 2010, 39, 638-655. (d) Chou, P.-T.; Chi, Y.; Chung, M.-W.; Lin, C.C. Coord. Chem. Rev. 2011, 255, 2653-2665. (e) Chi, Y.; Tong, B.; Chou, P.-T. Coord. Chem. Rev. 2014, 281, 1-25.

(3) (a) Crespo, O.; Eguillor, B.; Esteruelas, M. A.; Fernández, I.; García-Raboso, J.; Gómez-Gallego, M.; Martín-Ortiz, M.; Oliván, M.; Sierra, M. A. Chem. Commun. 2012, 48, 5328-5330. (b) Eguillor, B.; Esteruelas, M. A.; Fernández, I.; Gómez-Gallego, M.; Lledós, A.; Martín-Ortiz, M.; Oliván, M.; Oñate, E.; Sierra, M. A. Organometallics 2015, 34, 1898-1910.

(4) (a) Castro-Rodrigo, R.; Esteruelas, M. A.; López, A. M.; Oliván, M.; Oñate, E. Organometallics 2007, 26, 4498-4509. (b) Baya, M.; Esteruelas, M. A.; Oliván, M.; Oñate, E. Inorg. Chem. 2009, 48, 2677-2686.

(5) See for example: (a) Albrecht, M.; van Koten, G. Angew. Chem. Int. Ed. 2001, 40, 3750-3781. (b) van der Boom, M. E.; Milstein, D. Chem. Rev. 2003, 103, 1759-1792. (c) Benito-Garagorri, D.; Kirchner, K. Acc. Chem. Res. 2008, 41, 201-213. (d) Choi, J.; MacArthur, A. H. R.; Brookhart, M.; Goldman, A. S. Chem. Rev. 2011, 111, 1761-1779.

(6) Lu, C.-W.; Wang, Y.; Chi, Y. Chem. Eur. J. 2016, 22, 1789217908.

(7) (a) Koo, C.-K.; Lam, B.; Leung, S.-K.; Lam, M. H.-W.; Wong, W.-Y. J. Am. Chem. Soc. 2006, 128, 16434-16435. (b) Koo, C.-K.; Ho, Y.-M.; Chow, C.-F.; Lam, M. H.-W.; Lau, T.-C.; Wong, W.-Y. Inorg. Chem. 2007, 46, 3603-3612. (c) Koo, C.-K.; Wong, K.-L.; Lau, K.-C.; Wong, W.-Y.; Lam, M. H.-W. Chem. Eur. J. 2009, 15, 76897697. (d) Koo, C.-K.; Wong, K.-L.; Man, C. W.-Y.; Lam, Y.-W.; So, L. K.-Y.; Tam, H.-L.; Tsao, S.-W.; Cheah, K.-W.; Lau, K.-C.; Yang, Y.-Y.; Chen, J.-C.; Lam, M. H.-W. Inorg. Chem. 2009, 48, 872-878. (e) Koo, C.-K.; Wong, K.-L.; Man, C. W.-Y.; Tam, H.-L.; Tsao, S.W.; Cheah, K.-W.; Lam, M. H.-W. Inorg. Chem. 2009, 48, 75017503. (f) Koo, C.-K.; So, L. K.-Y.; Wong, K.-L.; Ho, Y.-M.; Lam, Y.W.; Lam, M. H.-W.; Cheah, K.-W.; Cheng, C. C.-W.; Kwok, W.-M. Chem. Eur. J. 2010, 16, 3942-3950. (g) Kataoka, Y., Kitagawa, Y.; Kawakami, T.; Okumura, M. J. Organomet. Chem. 2013, 743, 163169. (h) Tsai, J. L.-L.; Zou, T.; Liu, J.; Chen, T.; Chan, A. O.-Y.;
Yang, C.; Lok, C.-N.; Che, C.-M. Chem. Sci. 2015, 6, 3823-3830. (i) Jana, A.; McKenzie, L.; Wragg, A. B.; Ishida, M.; Hill, J. P.; Weinstein, J. A.; Baggaley, E.; Ward, M. D. Chem. Eur. J. 2016, 22, 41644174.

(8) (a) Tong, B.; Ku, H.-Y.; Chen, I.-J.; Chi, Y.; Kao, H.-C.; Yeh, C.-C.; Chang, C.-H.; Liu, S.-H.; Lee, G.-H.; Chou, P.-T. J. Mater. Chem. C 2015, 3, 3460-3471. (b) Kuei, C.-Y.; Tsai, W.-L.; Tong, B.; Jiao, M.; Lee, W.-K.; Chi, Y.; Wu, C.-C.; Liu, S.-H.; Lee, G.-H.; Chou, P.-T. Adv. Mater. 2016, 28, 2795-2800. (c) Lin, J.; Chau, N.Y.; Liao, J.-L.; Wong, W.-Y.; Lu, C.-Y.; Sie, Z.-T.; Chang, C.-H.; Fox, M. A.; Low, P. J.; Lee, G.-H.; Chi, Y. Organometallics 2016, 35, 1813-1824.

(9) See for example: (a) Castarlenas, R.; Esteruelas, M. A.; Oñate, E. Organometallics 2007, 26, 3082-3084. (b) Wong, C.-Y.; Lai, L.M.; Pat, P.-K.; Chung, L.-H. Organometallics 2010, 29, 2533-2539. (c) Asensio, G.; Cuenca, A. B.; Esteruelas, M. A.; Medio-Simón, M.; Oliván, M.; Valencia, M. Inorg. Chem. 2010, 49, 8665-8667. (d) Esteruelas, M. A.; Honczek, N.; Oliván, M.; Oñate, E.; Valencia, M. Organometallics 2011, 30, 2468-2471. (e) Alós, J.; Bolaño, T.; Esteruelas, M. A.; Oliván, M.; Oñate, E.; Valencia, M. Inorg. Chem. 2013, 52, 6199-6213. (f) Vega, E.; Lastra, E.; Gamasa, M. P. Inorg. Chem. 2013, 52, 6193-6198. (g) Alós, J.; Bolaño, T.; Esteruelas, M. A.; Oliván, M.; Oñate, E.; Valencia, M. Inorg. Chem. 2014, 53, 11951209. (h) Spasyuk, D.; Vicent, C.; Gusev, D. G. J. Am. Chem. Soc. 2015, 137, 3743-3746. (i) Alós, J.; Esteruelas, M. A.; Oliván, M.; Oñate, E.; Puylaert, P. Organometallics 2015, 34, 4908-4921. (j) Esteruelas, M. A.; García-Yebra, C.; Martín, J.; Oñate, E. Inorg. Chem. 2017, 56, 676-683.

(10) See for example: (a) Gusev, D. G.; Maxwell, T.; Dolgushin, F. M.; Lyssenko, M.; Lough, A. J. Organometallics 2002, 21, 1095-1100 (b) Wen, T. B.; Zhou, Z. Y.; Jia, G. Angew. Chem. Int. Ed. 2006, 45, 5842-5846. (c) Lee, J.-H.; Pink, M.; Caulton, K. G. Organometallics 2006, 25, 802-804. (d) Bossi, G.; Putignano, E.; Rigo, P.; Baratta, W. Dalton Trans. 2011, 40, 8986-8995. (e) Boff, B.; Gaiddon, C.; Pfeffer, M. Inorg. Chem. 2013, 52, 2705-2715. (f) Gruver, B. C.; Adams, J. J.; Arulsamy, N.; Roddick, D. M. Organometallics 2013, 32, 64686475. (g) Müller, A. L.; Wadepohl, H.; Gade, L. H. Organometallics 2015, 34, 2810-2818.

(11) See for example: (a) Esteruelas, M. A.; Fernández, I.; Herrera, A.; Martín-Ortiz, M.; Martínez-Alvarez, R.; Oliván, M.; Oñate, E.; Sierra, M. A.; Valencia, M. Organometallics 2010, 29, 976-986. (b) Ni, W.-X.; Man, W.-L.; Cheung, M. T.-W.; Sun, R. W.-Y.; Shu, Y.L.; Lam, Y.-W.; Che, C.-M.; Lau, T.-C. Chem. Commun. 2011, 47, 2140-2142.

(12) Casarrubios, L.; Esteruelas, M. A.; Larramona, C.; Muntaner, J. G.; Oñate, E.; Sierra, M. A. Inorg. Chem. 2015, 54, 10998-11006.

(13) Eguillor, B.; Esteruelas, M. A.; Lezáun, V.; Oliván, M.; Oñate, E.; Tsai, J.-Y.; Xia, C. Chem. Eur. J. 2016, 22, 9106-9110.

(14) Eguillor, B.; Esteruelas, M. A.; Lezáun, V.; Oliván, M.; Oñate, E. Chem. Eur. J. 2017, 23, 1526-1530.

(15) See for example: (a) Baya, M.; Eguillor, B.; Esteruelas, M. A.; Lledós, A.; Oliván, M.; Oñate, E. Organometallics 2007, 26, 51405152. (b) Esteruelas, M. A.; Forcén, E.; Oliván, M.; Oñate, E. Organometallics 2008, 27, 6188-6192. (c) Esteruelas, M. A.; Masamunt, A. B.; Oliván, M.; Oñate, E.; Valencia, M. J. Am. Chem. Soc. 2008 130, 11612-11613. (d) Bolaño, T.; Esteruelas, M. A.; Fernández, I.; Oñate, E.; Palacios, A.; Tsai, J.-Y.; Xia, C. Organometallics 2015, 34 , 778-789. (e) Esteruelas, M. A.; Larramona, C.; Oñate, E. Organometallics 2016, 35, 1597-1600.

(16) (a) Esteruelas, M. A.; Lahoz, F. J.; López, A. M.; Oñate, E.; Oro, L. A.; Ruiz, N.; Sola, E.; Tolosa, J. I. Inorg. Chem. 1996, 35, 7811-7817. (b) Esteruelas, M. A.; García-Raboso, J.; Oliván, M. Organometallics 2011, 30, 3844-3852. (c) Esteruelas, M. A.; GarcíaRaboso, J.; Oliván, M.; Oñate, E. Inorg. Chem. 2012, 51, 5975-5984. (d) Esteruelas, M. A.; García-Raboso, J.; Oliván, M. Inorg. Chem. 2012, 51, 9522-9528. (e) Casarrubios, L.; Esteruelas, M. A.; Larramona, C.; Muntaner, J. G.; Oliván, M.; Oñate, E.; Sierra, M. A. Organometallics 2014, 33, 1820-1833.

(17) Esteruelas, M. A.; López, A. M.; Oliván, M. Chem. Rev. 2016, $116,8770-8847$ 
(18) See for example: (a) Buil, M. L.; Esteruelas, M. A.; Garcés, K.; Oliván, M.; Oñate, E. J. Am. Chem. Soc. 2007, 129, 10998-10999. (b) Buil, M. L.; Esteruelas, M. A.; Garcés, K.; Oliván, M.; Oñate, E. Organometallics 2008, 27, 4680-4690. (c) Buil, M. L.; Esteruelas, M. A.; Garcés, K.; Oñate, E. J. Am. Chem. Soc. 2011, 133, 2250-2263.

(19) The H-H distances were calculated from the $T_{1}(\mathrm{~min})$ values applying the equation $R_{\mathrm{H}-\mathrm{H}}=129.18 / \mathrm{r}_{\mathrm{H}-\mathrm{H}}{ }^{6}$, where $R_{\mathrm{H}-\mathrm{H}}=R_{\mathrm{n}}-R^{*}\left(R_{\mathrm{n}}\right.$ is the relaxation rate due to the dipole-dipole interaction, and is equal to $1 / T_{1}(\mathrm{~min})$ at $300 \mathrm{MHz}$, and $R^{*}$ is the relaxation rate due to all other relaxation contributors of the molecule and is estimated to be $2.5 \mathrm{~s}^{-1}$ ). See: Castillo, A.; Esteruelas, M. A.; Oñate, E.; Ruiz, N. J. Am. Chem. Soc. 1997, 119, 9691-9698.

(20) Sabo-Etienne, S.; Chaudret, B. Chem. Rev. 1998, 98, 20772091.

(21) $J_{\mathrm{mag}}$ is the portion of $J_{\text {obs }}$ due to the Fermi contact interaction; parameter $\lambda$ is the hard sphere radius of the hydrides, and $v$ describes the $\mathrm{H}-\mathrm{M}-\mathrm{H}$ vibrational wag mode that allows the movement along the $\mathrm{H}-\mathrm{H}$ vector.

(22) Morris, R. H. Chem. Rev. 2016, 116, 8588-8654

(23) (a) Masciocchi, N.; Galli, S.; Alberti, E.; Sironi, A.; Di Nicola, C.; Pettinari, C.; Pandolfo, L. Inorg. Chem. 2006, 45, 9064-9074. (b) Brandi-Blanco, P.; Sanz Miguel, P. J.; Lippert, B. Eur. J. Inorg. Chem. 2012, 2012, 1122-1129.

(24) Bruce, M. I.; Ellis, B. G.; Skelton, B. W.; White, A. H. J. Organomet. Chem. 2004, 689, 698-701.

(25) Chen, Y.; Wang, D.; Petersen, J. L.; Akhmedov, N. G.; Shi, X. Chem. Commun. 2010, 46, 6147-6149.

(26) Minghetti, G.; Cinellu, M. A.; Pinna, M. V.; Stoccoro, S.; Zucca, A.; Manassero, M. J. Organomet. Chem. 1998, 568, 225-232.

(27) For examples of pyrazole-based remote NHC ligands see: (a) Han, Y.; Huynh, H. V. Chem. Commun. 2007, 1089-1091. (b) Han, Y.; Huynh, H. V.; Tan, G. K. Organometallics 2007, 26, 6581-6585. (c) Han, Y.; Lee, L. J.; Huynh, H. V. Organometallics 2009, 28, 2778-2786. (d) Han, Y.; Lee, L. J.; Huynh, H. V. Chem. Eur. J. 2010, 16, 771-773. (e) Han, Y.; Yuan, D.; Teng, Q.; Huynh, H. V. Organometallics 2011, 30, 1224-1230.

(28) For osmium complexes containing pyrazolate-pyridyl ligands see: (a) Wu, P.-C.; Yu, J.-K.; Song, Y.-H.; Chi, Y.; Chou, P.-T.; Peng, S.-M.; Lee, G.-H. Organometallics 2003, 22, 4938-4946. (b) Tung, Y.-L.; Wu, P.-C.; Liu, C.-S.; Chi, Y.; Yu, J.-K.; Hu, Y.-H.; Chou, P.T.; Peng, S.-M.; Lee, G.-H.; Tao, Y.; Carty, A. J.; Shu, C.-F.; Wu, F.I. Organometallics 2004, 23, 3745-3748. (c) Li, S.-W.; Cheng, Y.-M.; Yeh, Y.-S.; Hsu, C.-C.; Chou, P.-T.; Peng, S.-M.; Lee, G.-H.; Tung, Y.-L.; Wu, P.-C.; Chi, Y.; Wu, F.-I.; Shu, C.-F. Chem. Eur. J. 2005, 11, 6347-6357. (d) Niu, Y.-H.; Tung, Y.-L.; Chi, Y.; Shu, C.-F.; Kim, J. H.; Chen, B.; Luo, J.; Carty, A. J.; Jen, A. K.-Y. Chem. Mater. 2005, 17, 3532-3536. (e) Lu J.; Tao, Y.; Chi, Y.; Tung, Y. Synthetic Met. 2005, 155, 56-62. (f) Hsu, F.-C.; Tung, Y.-L.; Chi, Y.; Hsu, C.C.; Cheng, Y.-M.; Ho, M.-L.; Chou, P.-T.; Peng, S.-M.; Carty, A. J. Inorg. Chem. 2006, 45, 10188-10196. (g) Cheng, Y.-M.; Li, E. Y.; Lee, G.-H.; Chou, P.-T.; Lin, S.-Y.; Shu, C.-F.; Hwang, K.-C.; Chen, Y.-L.; Song, Y.-H.; Chi, Y. Inorg. Chem. 2007, 46, 10276-10286. (h) Cheng, Y.-M.; Lee, G.-H.; Chou, P.-T.; Chen, L.-S.; Chi, Y.; Yang, C.-H.; Song, Y.-H.; Chang, S.-Y.; Shih, P.-I.; Shu, C.-F. Adv. Funct. Mater. 2008, 18, 183-194. (i) Chang, S.-H.; Chang, C.-F.; Liao, J.-L.; Chi, Y.; Zhou, D.-Y.; Liao, L.-S.; Jiang, T.-Y.; Chou, T.-P.; Li, E. Y.; Lee, G.-H.; Kuo, T.-Y.; Chou, P.-T. Inorg. Chem. 2013, 52, 58675875 .

(29) Esteruelas, M. A.; Oliván, M.; Vélez, A. Inorg. Chem. 2013, $52,12108-12119$

(30) Neutral compounds offer opportunities for the fabrication of OLEDs by the vapor deposition method. See for example: (a) Xiao, L.; Chen, Z.; Qu, B.; Luo, J.; Kong, S.; Gong, Q.; Kido, J. Adv. Mater. 2011, 23, 926-952. (b) Ho, C.-L.; Li, H.; Wong, W.-Y. J. Organomet. Chem. 2014, 751, 261-285. (c) Fan, C.; Yang, C. Chem. Soc. Rev. 2014, 43, 6439-6469. (d) Jou, J.-H.; Kumar, S.; Agrawal, A.; Li, T.-H.; Sahooa, S. J. Mater. Chem. C 2015, 3, 2974-3002.

(31) Emissive salts are candidates for light-emitting electrochemical cells. See for example: (a) Slinker, J. D.; Rivnay, J.; Moskowitz, J. S.; Parker, J. B.; Bernhard, S.; Abruña, H. D.; Malliaras, G. G. J. Mater. Chem. 2007, 17, 2976-2988. (b) Hu, T.; He, L.; Duan, L.; Qiu,
Y. J. Mater. Chem. 2012, 22, 4206-4215. (c) Costa, R. D.; Ortí, E.; Bolink, H. J.; Monti, F.; Accorsi, G.; Armaroli, N. Angew. Chem. Int Ed. 2012, 51, 8178-8211. (d) Meier, S. B.; Tordera, D.; Pertegás, A.; Roldán-Carmona, C.; Ortí, E.; Bolink, H. J. Mater. Today 2014, 17, 217-223. (e) Henwood, A. F.; Zysman-Colman, E. Top. Curr. Chem. 2016, 374, 36. (f) Tang, S.; Edman, L. Top. Curr. Chem. 2016, 374 40 .

(32) Crabtree, R. H. Chem. Rev. 2016, 116, 8750-8769.

(33) Xia, C.; Tsai, J.-Y.; Esteruelas, M. A.; Gómez, R.; Oliván, M.; Oñate, E. US Patent Application 14/996448, 2016

(34) Aracama, M.; Esteruelas, M. A.; Lahoz, F. J.; Lopez, J. A.; Meyer, U.; Oro, L. A.; Werner, H. Inorg. Chem.1991, 30, 288-293.

(35) Blessing, R. H. Acta Crystallogr. 1995, A51, 33-38. SADABS: Area-detector absorption correction; Bruker- AXS, Madison, WI, 1996.

(36) SHELXTL Package v. 6.14; Bruker-AXS, Madison, WI, 2000.Sheldrick, G. M. Acta Cryst. 2008, A64, 112-122.

(37) (a) Lee, C.; Yang, W.; Parr, R. G. Phys. Rev. B 1988, 37, 785789. (b) Becke, A. D. J. Chem. Phys. 1993, 98, 5648-5652. (c) Stephens, P. J.; Devlin, F. J.; Chabalowski, C. F.; Frisch, M. J. J. Phys. Chem. 1994, 98, 11623-11627.

(38) Grimme, S.; Antony, J.; Ehrlich, S.; Krieg, H. J. Chem. Phys. 2010, 132, 154104.

(39) Frisch, M. J.; Trucks, G. W.; Schlegel, H. B.; Scuseria, G. E.; Robb, M. A.; Cheeseman, J. R.; Scalmani, G.; Barone, V.; Mennucci, B.; Petersson, G. A.; Nakatsuji, H.; Caricato, M.; Li, X.; Hratchian, H. P.; Izmaylov, A. F.; Bloino, J.; Zheng, G.; Sonnenberg, J. L.; Hada, M.; Ehara, M.; Toyota, K.; Fukuda, R.; Hasegawa, J.; Ishida, M.; Nakajima, T.; Honda, Y.; Kitao, O.; Nakai, H.; Vreven, T.; Montgomery, J. A., Jr.; Peralta, J. E.; Ogliaro, F.; Bearpark, M.; Heyd, J. J.; Brothers, E.; Kudin, K. N.; Staroverov, V. N.; Kobayashi, R.; Normand, J.; Raghavachari, K.; Rendell, A.; Burant, J. C.; Iyengar, S. S.; Tomasi, J.; Cossi, M.; Rega, N.; Millam, N. J.; Klene, M.; Knox, J. E.; Cross, J. B.; Bakken, V.; Adamo, C.; Jaramillo, J.; Gomperts, R.; Stratmann, R. E.; Yazyev, O.; Austin, A. J.; Cammi, R.; Pomelli, C.; Ochterski, J. W.; Martin, R. L.; Morokuma, K.; Zakrzewski, V. G.; Voth, G. A.; Salvador, P.; Dannenberg, J. J.; Dapprich, S.; Daniels, A. D.; Farkas, Ö.; Foresman, J. B.; Ortiz, J. V.; Cioslowski, J.; Fox, D. J. Gaussian 09, Revision B.01; Gaussian, Inc., Wallingford, CT, 2009.

(40) Andrea, D.; Haeussermann, U. M.; Dolg, M.; Stoll, H.; Preuss, H. Theor. Chim. Acta 1990, 77, 123-141.

(41) Ehlers, A. W.; Bohme, M.; Dapprich, S.; Gobbi, A.; Hollwarth, A.; Jonas, V.; Kohler, K. F.; Stegmann, R.; Veldkamp, A.; Frenking, G. Chem. Phys. Lett. 1993, 208, 111-114.

(42) (a) Hehre, W. J.; Ditchfield, R.; Pople, J. A. J. Chem. Phys. 1972, 56, 2257-2261. (b) Francl, M. M.; Pietro, W. J.; Hehre, W. J.; Binkley, J. S.; Gordon, M. S.; DeFrees, D. J.; Pople, J. A. J. Chem. Phys. 1982, 77, 3654-3665.

(43) Marenich, A. V.; Cramer, C. J.; Truhlar, D. G. J. Phys. Chem. B 2009, 113, 6378-6396.

(44) O'Boyle, N. M.; Tenderholt, A. L.; Langner, K. M. J. Comput. Chem. 2008, 29, 839-845. 


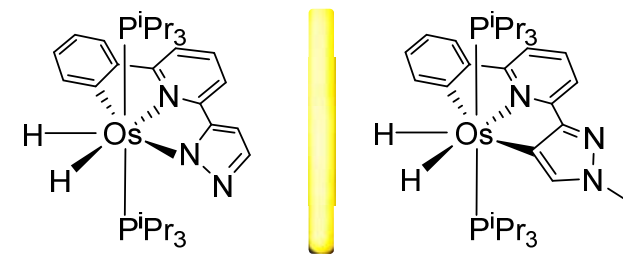

